\title{
Site Descriptions of High-Quality Wetlands Derived from Existing Literature Sources
}

\author{
Prepared for: \\ The Montana Department \\ of Environmental Quality \\ By: \\ S. V. Cooper and W. M. Jones
}

Montana Natural Heritage Program

Natural Resource Information System

Montana State Library

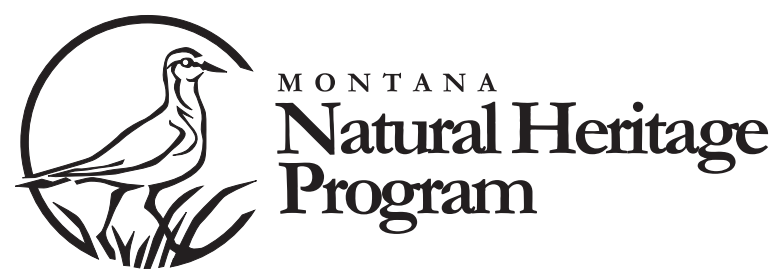




\title{
Site Descriptions of High-Quality Wetlands Derived from Existing Literature Sources
}

\author{
Prepared for: \\ The Montana Department \\ of Environmental Quality
}

Contract Number:

200102

By:

S. V. Cooper and W. M. Jones
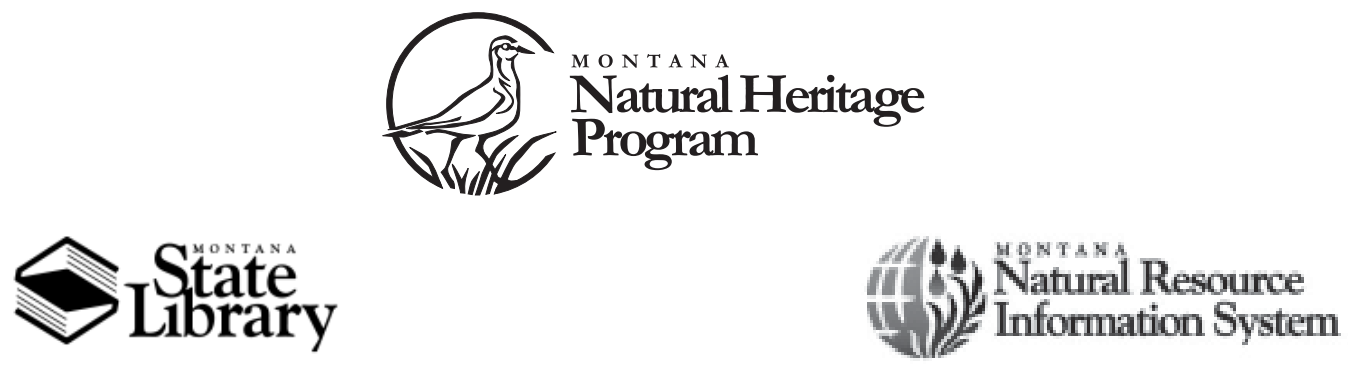

(C) 2003 Montana Natural Heritage Program

P.O. Box 201800 • 1515 East Sixth Avenue • Helena, MT 59620-1800 • 406-444-5354 
The preferred citation for this document is:

Cooper, S. V. and W. M. Jones. 2003. Site descriptions of high-quality wetlands derived from existing literature sources. Report to the Montana Department of Environmental Quality. Montana Natural Heritage Program, Helena. 68 pp. + appendix. 


\section{TABLE OF CONTENTS}

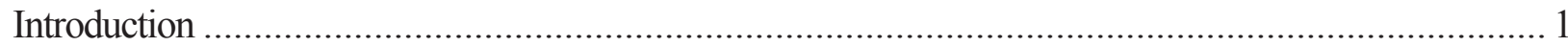

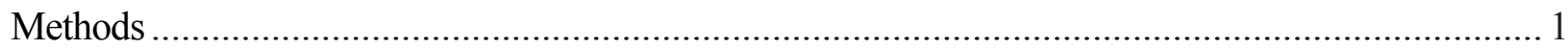

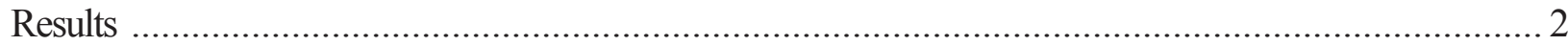

Site Descriptions

American Fork Foothills Wetlands ........................................................................... 4

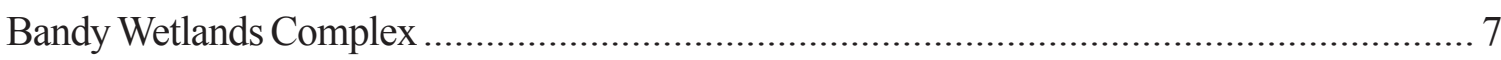

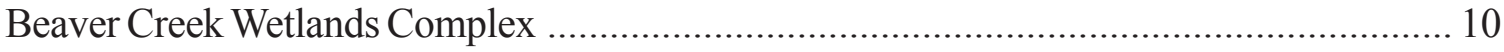

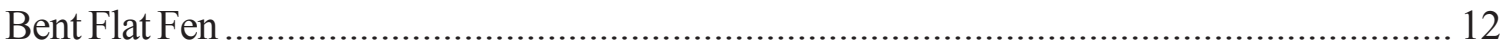

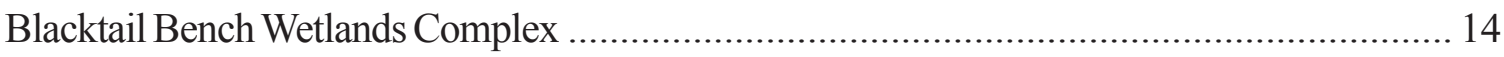

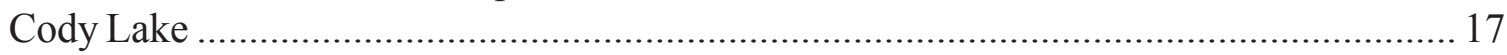

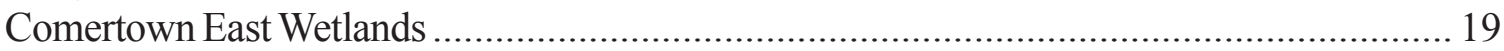

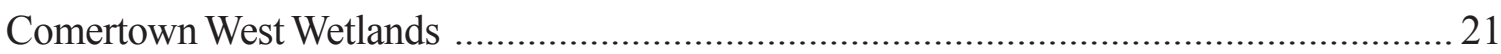

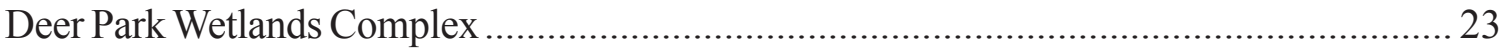

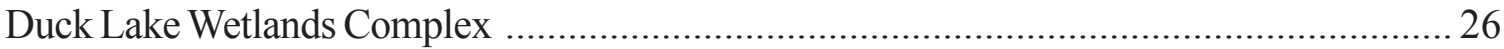

East Glacier Wetlands Complex ............................................................................... 30

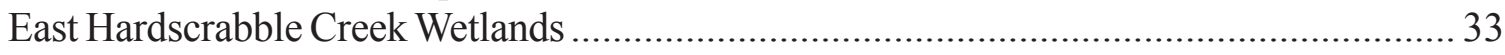

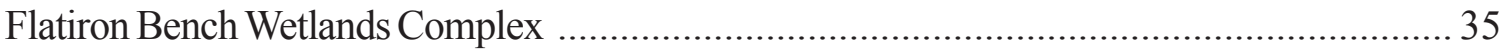

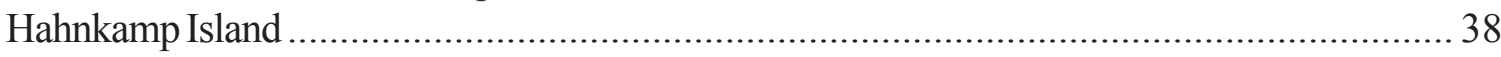

Harkness Lakes Wetlands Complex ........................................................................... 40

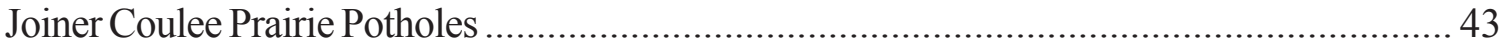

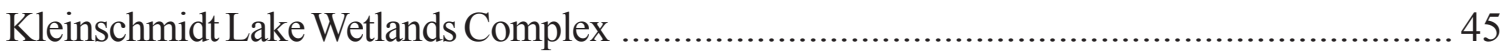

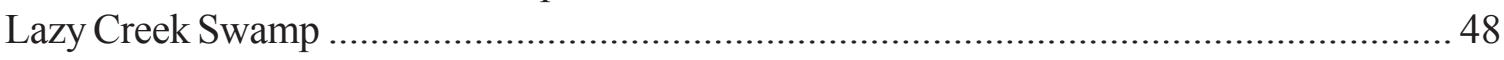

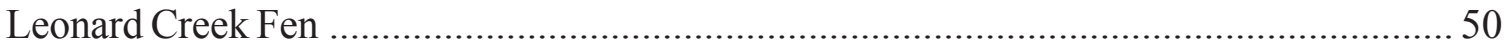

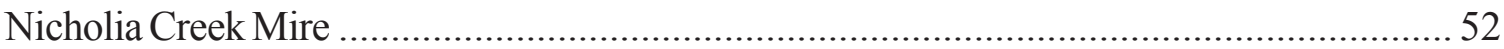

North Fork Burns Creek Draws .............................................................................. 54

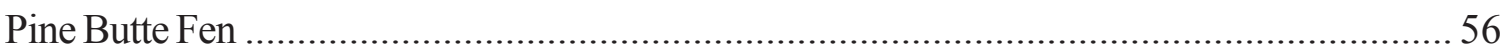

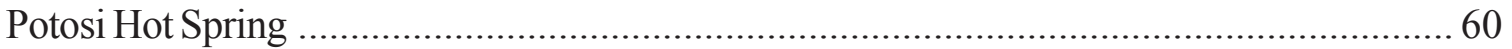

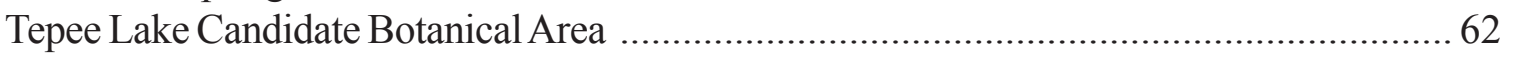

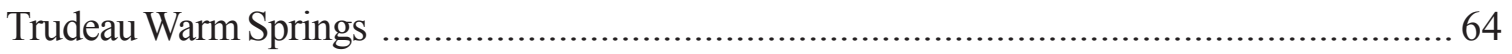

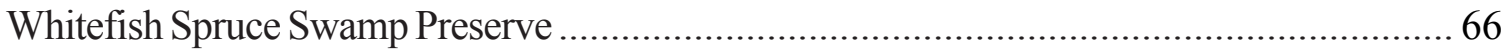

Appendix A. Global/State Rank Definitions 


\section{Introduction}

Although the Montana Natural Heritage Program (MTNHP) has pursued an active program of field investigations to identify and sample high quality wetlands and riparian areas, there has been considerable inventory conducted by other qualified investigators of various affiliations. MTNHP proposed to assemble available wetland/riparian data from major sources, review it, extract relevant information, and make extracted information publicly available via our web site. It should be emphasized that we are not merely repackaging information; we are gleaning, interpreting and assessing information so as to identify and describe only the highest quality wetlands

We placed an emphasis on collecting information from western Montana (west of the Continental Divide, or in the near vicinity of, if east of it) because the results would inform ongoing field investigations in this area, prevent overlapping sampling, and place recent and ongoing field results in a larger ecological context. Following consultation with The Wetland Council, we determined priority data sources reviewed to be special reports (particularly inventories) prepared for the Montana Field Office of The Nature Conservancy, research conducted by university scientists, the plot database of Riparian and Wetland Research Program at the School of Forestry, University of Montana, U.S. Forest Service peatland inventories, and existing records in the MTNHP plots database.

\section{Methods}

Each of the following headings in the report constitute fields that will be populated in a MTNHP database by information extracted from a given data source for a single site:

- Site Name: Either listed as the project name or chosen to be representative of a given locality.

- Directions: A general location and regional setting within the state is presented and then follows a detailed description of the most convenient way to access the site (with accompanying mileages from prominent locations). To avoid trespass issues, it was noted whether a site was located either wholly or partly on private lands.

- Description: This field describes the physiographic setting and unique landscape features, if any. A narrative follows enumerating the plant communities present and describing their environmental setting and species composition. A concerted effort was made to crosswalk communities to the National Vegetation Classification System (NVCS), a standardized system used to facilitate inventory, communication and extrapolation of results.

- Key Environmental Factors: This field relates to the immediate wetland or riparian area and not its landscape context (see Land Use). Considering that this project is focused on wetlands and riparian areas the primary driving variables of community structure and composition almost invariably relate to hydrology. Often this field contains conjecture (explicitly stated) because hard data on hydrology is seldom recorded or is reported from a one-time visit and can extend to off-site considerations, such as a flow regulation by an upstream dam. Other factors may be relevant such as browsing by herbivores (e.g., beavers) that could alter composition and structure.

- Rarity: Noted here are all rare elements tracked by the MTNHP including species (plants, both vascular \& non-vascular, and animals) and communities. Element degree of imperilment may be found in "Plant Species of Concern" and "Animal Species of Concern" (distributed by the MTNHP).

- Other Values: This field addresses the overall significance of the wetland/riparian area and places it into regional or state context in terms of unique communities, their extent (size) and condition.

- Land Use: Usually pertains to man's manipulation of the environment/landscape, such as farming, tree harvesting, and livestock operations. 
- Exotics: Both noxious weeds and exotic (introduced) species are noted, including seeded "pasture" grasses (e.g., Phleum pratense (timothy), Poa pratensis (Kentucky bluegrass) and Bromus inermis (smooth brome)). This field can have strong bearing on the overall significance of the wetland as a conservation area. Baring wholesale development, exotics are potentially the greatest threat to species diversity and ecosystem function.

- Uplands: These systems provide the context for the embedded wetlands; if the uplands are severely impacted, then embedded wetlands will also likely be degraded.

- Information Needs: All degrees of inventory intensity were encountered; sometimes communities were noted by name but their composition not documented and, most significantly, the exotic populations were not documented. Often upland land practices, condition, or exotic populations were not documented, all of which have a distinct bearing on the wetland's viability.

- Management Needs: This field is often tied to "Information Needs" because additional data is often necessary before management recommendations can be made.

- Source: A full citation is given for the literature or origin of the information from which this depiction and analysis was abstracted; source abstract number assigned by MTNHP is cited.

\section{Results}

The Wetland Council queried key wetland experts and scientists to identify priority and perhaps overlooked wetland data sources: no unanticipated data sources surfaced and the above-cited sources were targeted for data extraction and analysis. The targeted data sources were contacted and the appropriate documents were acquired. The most relevant, prolific, and reputable sources were inventories conducted by Peter Lesica for The Nature conservancy; these documents largely resided as hardcopy reports on file with the Montana Field Office of TNC. An anticipated source, the plot files of the Riparian and Wetland Research Program proved to be not so fruitful because it consisted of plots and not sites; only with considerable difficulty could it be determined whether the plot was representative of a greater whole that would constitute a site.

Twenty-six high-quality wetland sites were identified and described. Most of these occurred in western Montana, although wetlands in north central and northeastern Montana are also represented (Figure 1). 


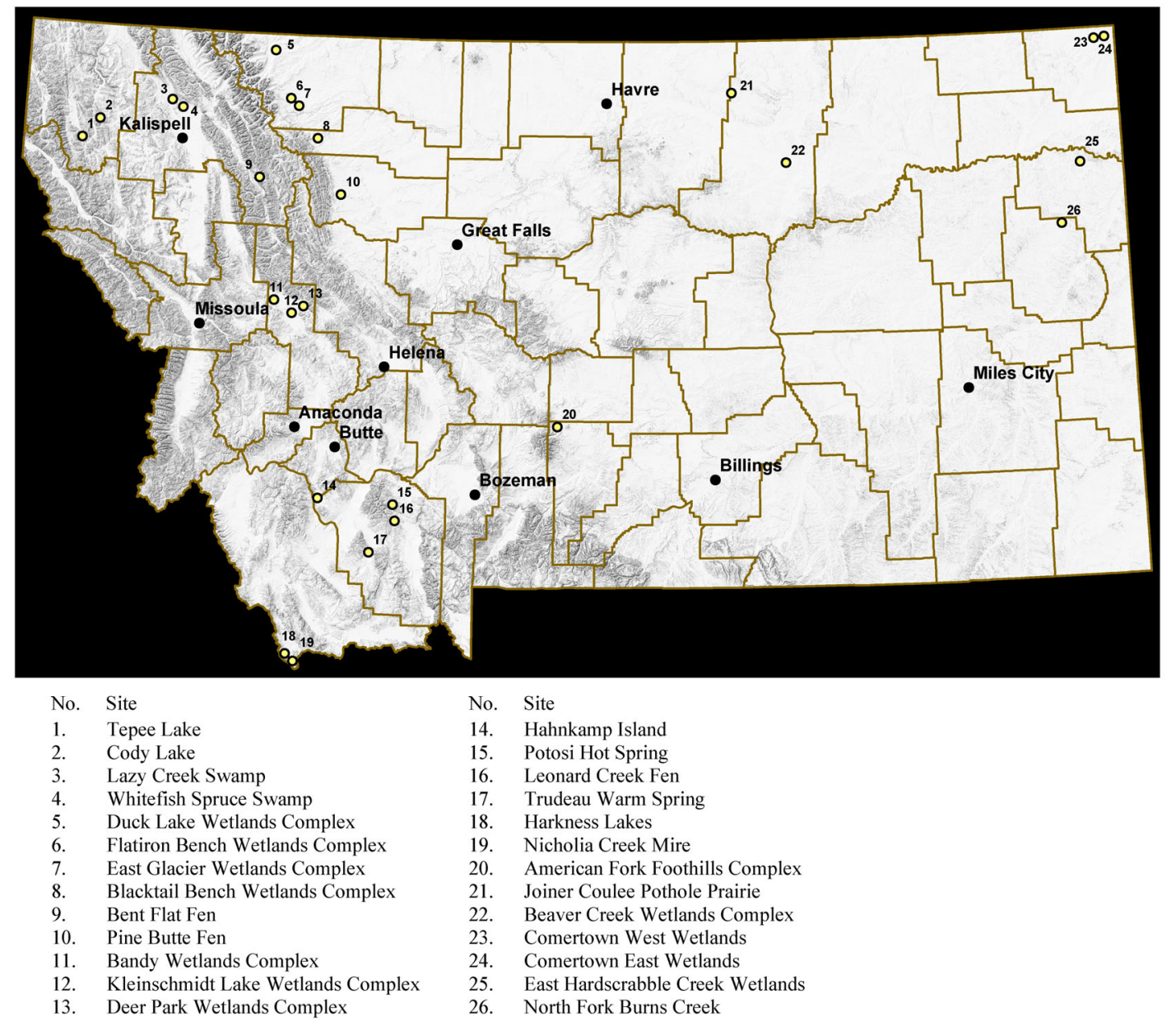

Figure 1. Location of Wetland Sites 


\section{American Fork Foothills Wetlands}

\section{Directions}

Portions of this site are located on private land and landowner permission is required to access these privately held areas. The American Fork Foothills is found on the east slopes of the Crazy Mountains, approximately 30 air miles north of Big Timber in Sweet Grass County. This site may be approached from either Big Timber or Harlowton on US 91. From Melville on Montana 287 drive to the pavement's end (9 miles) and continue another 9 miles on the unpaved road that gradually narrows to a large stone gate on the left, marked clearly "American Fork". From ranch compound take road between American Fork Creek and Agnes Creek approximately three miles to a point where the dispersed wetlands are easily accessed.

\section{Description}

This area is bounded on the south by Sweet Grass Creek and on the north by O'Hearn Creek. The wetlands range in elevation from 5,700 to 6,400 feet. This site is a mosaic or wetlands complex composed of riparian wetlands associated with the American Fork River and Sweet Grass Creek, as well as glacial wetlands associated with pothole depressions created by valley glaciers in the Crazy Mountains foothills. The site derives its name from the American Fork River, which courses through the center of the area as a free flowing and actively channel cutting river on which extensive Populus balsamifera ssp. trichocarpa (black cottonwood)-dominated riparian forests occur, including both early seral stands on gravel bars and mature stands on stabilized terraces. Common forest undergrowth shrubs include Symphoricarpos occidentalis (western snowberry), Ribes spp. (gooseberry), and Elaeagnus commutata (silverberry). The herbaceous component, especially the dominance of pasture grasses Poa pratensis (Kentucky bluegrass) Phleum pratense (timothy), reflects significant past disturbance (grazing); other common herbs include Solidago canadensis (Canada goldenrod), Viola canadensis (Canada violet), Fragaria virginiana (strawberry), Allium brevistylum (short-style onion), Osmorhiza chilensis (mountain sweet-cicely) and Galium boreale (northern bedstraw). Extensive Salix (willow)-dominated swamps have generated behind beaver dams on Agnes Creek. Dominant Salix spp. include Salix exigua (sandbar willow), Salix drummondiana (Drummond willow) and Salix eriocephala (MacKenzie willow). Carex utriculata (beaked sedge) and Carex aquatilis (water sedge) dominate under the willow canopies, with the common forbs being Angelica arguta (angelica) and Heracleum lanatum (cow parsnip). Open water aquatic communities (ponds and stream channels) are dominated by Hippuris vulgaris (Mare's-tail) and Myriophyllum sibiricum (water milfoil). Riparian meadow communities span the gradient between wet riparian and upland. A portion of these extensive meadows is Symphoricarpos occidentalis-dominated shrubland, a community that is only marginally wetland; Rosa woodsii (Wood's rose) is often co-dominant in this shrubland. Dominant graminoids occurring under the Symphoricarpos canopy as well as standing alone and in various combinations as meadow dominants include Elymus trachycaulus (bearded wheatgrass), Juncus balticus (Baltic rush), Poa pratensis and Phleum pratense. Common forbs of these moist meadows include Galium boreale (northern bedstraw), Monarda fistulosa (wild bergamot), Senecio serra (tall butterweed), and Solidago gigantea (tall goldenrod).

Wetlands plant communities associated with ponds and seep areas between major drainages include wet meadows where water is ponded in the spring and early summer. Though water regime is not the only factor structuring the following graminoid-dominated plant associations, they have been listed in the approximate order of wettest (longest period of inundation) to driest; Carex nebrascensis (Nebraska sedge); Juncus balticus (Baltic rush); Carex pellita (= Carex lanuginosa, wooly sedge); Deschampsia caespitosa (tufted hairgrass); Hordeum jubatum (foxtail barley). Marsh vegetation dominates the mineral substrates of shallow permanent ponds with the following plant associations being most common; Eleocharis palustris (common spikerush); Beckmannia syzigachne (sloughgrass); Potamogeton gramineus (grass-leaved 
pondweed); Polygonum amphibium (water smartweed); Schoenoplectus pectinatus - Myriophyllum sibiricum (fennel-leaved pondweed - water milfoil). At the heads of minor drainages organic soils support fens and communities dominated by and named for the following graminoids; Carex simulata (shortbeaked sedge); Carex utriculata (beaked sedge); Carex nebrascensis (Nebraska sedge); Juncus balticus (Baltic rush). Deschampsia caespitosa and Carex pellita are graminoids that occur in fens but are more characteristic of wet meadows where mineral soils are found. Common forbs of these fens include Senecio pauperculus (balsam groundsel), Senecio hydrophilus (alkali-marsh butterweed), Zigadenus elegans (glaucus death-camas), whereas Trifolium longipes (long-stalked clover) is more associated with wet meadows.

Grasslands are the dominant upland vegetation type and the most prevalent community type is Festuca idahoensis - Pascopyrum smithii (Idaho fescue - western wheatgrass). This community type is recognized based on the presumed ecological equivalence of Elymus lanceolatus (thick-spike wheatgrass, dominant in the landscape) and Pascopyrum smithii (minor component at American Fork). In addition to the nominal grasses other important graminoids include Koeleria macrantha (prairie junegrass), Pseudoroegneria spicata (bluebunch wheatgrass), Carex filifolia (threadleaf sedge) and Carex duriuscula (narrow-leaf sedge). Common forbs are Antennaria microphylla (rosey pussey-toes), Lupinus sericeus (silky lupine), Galium boreale (northern bedstraw) and Artemisia frigida (fringed sagewort). Open woodlands on steep north-facing slopes are dominated by Pinus flexilis (limber pine) and classed as the Pinus flexilis / Festuca idahoensis community. The undergrowth is relatively diverse with a thin cover of shrubs, Rosa woodsii (Wood's rose), Symphoricarpos occidentalis (western snowberry) and Dasiphora fruticosa (shrubby cinquefoil); forbs include Geranium viscosissimum (sticky geranium), Lupinus sericeus and Galium boreale.

\section{Key Environmental Factors}

Water is supplied to the shallow depressional wetlands from Crazy Mountains snowpack melt; a substrate of restricted permeability within the valley results in a seasonally perched water table. Beaver activity and free-flowing streams are important for long-term conservation of riparian-associated wetlands, especially cottonwood stands.

\section{Rarity}

The rare Ranunculus cardiophyllus (heart-leaved buttercup) is locally common in moist meadows ecotonal between wet meadow and upland grasslands. A sighting of Canada lynx (Felis lynx) has been reported from the wetland.

\section{Other Values}

According to the source report's author the assemblage of wetland types (riparian features associated with rivers and streams, spring creeks, ponds, fens, marshes, swamps, depressional wetlands) and the associated myriad plant associations exceeds that of any other Montana landscape, with the possible exception of the Blackfeet Reservation and the Ovando Valley. However, the latter two areas are much more extensive and have exhibit a greater diversity of water chemistry.

\section{Land Use}

Livestock grazing occurs over this whole landscape, including the wetland complex, and has created trails.

\section{Exotics}

This component was not explicitly inventoried but the exotic weeds Taraxacum officinale (common dandelion), Cynoglossum officinale (hound's-tongue), Poa pratensis (Kentucky bluegrass) and Phleum prat- 
ense (timothy) are common to dominant in the Populus balsamifera-dominated riparian forests. The exotics Carum carvi (caraway) and Cirsium vulgare (bull thistle) were also noted but not attributed to a specific wetland habitat.

\section{Uplands}

Cursory examination of the uplands revealed them to be extensively grazed, but still in fair to good ecological condition.

\section{Information Needs}

A thorough inventory needs to be conducted on the Rein Ranch for plant communities, sensitive species and exotics (initial survey had a very restricted access time). The grazing history should also be ascertained to determine its effect on the introduction of exotics and the alteration of community composition. Land practices on the uplands need documentation.

\section{Management Needs}

An inventory for weeds needs to be undertaken. Those of noxious status should be eradicated and a plan implemented to reduce or at least curtail the spread of exotic pasture grasses and other exotics.

\section{Source}

Lesica, P. 1987. Vegetation and flora of the American Fork Foothills Area, Sweet Grass County, Montana. Final report to the Montana/Wyoming Field Office, The Nature Conservancy, Helena.

\section{Element Occurrence Information}

\begin{tabular}{lcc}
\hline & \multicolumn{2}{c}{ Rarity Ranks } \\
Plant Association / Dominance Type & State & Global \\
\hline Alnus viridis ssp. sinuata Shrubland & $\mathrm{S} 2$ & $\mathrm{G} ? \mathrm{Q}$ \\
Carex nebrascensis Herbaceous Vegetation & $\mathrm{S} 4$ & $\mathrm{G} 4$ \\
Carex pellita Herbaceous Vegetation & $\mathrm{S} 3 ?$ & $\mathrm{G} 3$ \\
Carex simulata Herbaceous Vegetation & $\mathrm{S} 3$ & $\mathrm{G} 4$ \\
Carex utriculata Herbaceous Vegetation & $\mathrm{S} 5$ & $\mathrm{G} 5$ \\
Deschampsia caespitosa Herbaceous Vegetation & $\mathrm{S} 4$ & $\mathrm{G} 4$ \\
Eleocharis palustris Herbaceous Vegetation & $\mathrm{S} 5$ & $\mathrm{G} 5$ \\
Hordeum jubatum Herbaceous Vegetation & $\mathrm{S} 4$ & $\mathrm{G} 4$ \\
Juncus balticus Herbaceous Vegetation & $\mathrm{S} 5$ & $\mathrm{G} 5$ \\
Polygonum amphibium Permanently Flooded Herbaceous Alliance & $\mathrm{S} ?$ & $\mathrm{G} 5$ \\
Populus balsamifera ssp. trichocarpa / Cornus sericea Forest & $\mathrm{S} 3 ?$ & $\mathrm{G} 3 ?$ \\
Populus balsamifera ssp. trichocarpa / Mixed Herbs Forest & $*$ & $\mathrm{G} 3 ?$ \\
Populus balsamifera ssp. trichocarpa / Symphoricarpos occidentalis For- & & \\
est & $*$ & $\mathrm{G} 2 ?$ \\
Symphoricarpos occidentalis Shrubland & $\mathrm{S} 4 \mathrm{~S} 5$ & $\mathrm{G} 4 \mathrm{G} 5$ \\
Salix drummondiana Shrubland & $\mathrm{S} 3$ & $\mathrm{G} 3 \mathrm{Q}$ \\
Salix drummondiana / Carex utriculata Shrubland & $\mathrm{S} 4$ & $\mathrm{G} 4$ \\
Salix eriocephala Shrubland & $*$ & $*$ \\
Salix exigua Shrubland & $\mathrm{S} 5$ & $\mathrm{G} 5$ \\
\hline
\end{tabular}

* Rank not assigned 


\section{Bandy Wetlands Complex}

\section{Directions}

A portion of this site is located on private land; landowner permission is required to access that area. Access this area from the west on State Route 200 approximately 6 miles east of Clearwater Crossing (Junction?) turning north on Powell County Rd. 105; access from the east via State Route 200 approximately 6.8-7.0 miles west of Ovando Junction with County Rd. 107 turning north on Powell County Rd. 105. Drive north on Rd. 105 about 1.4 miles to where County Rd. 146 branches to the west. This position lies at the west central extremity of the wetlands complex from which the rest of the wetlands need to be accessed by foot.

\section{Description}

The majority of the wetlands and ponds in this area occur on the Bandy Ranch, the Barbour Ranch or the Murphy Ranch. This complex site occupies a wide portion if the Blackfoot River Valley in the vicinity of the town of Ovando. The nearly stagnant piedmont glaciers of the latter Pleistocene Era occupied most of the area north of the river depositing large amounts of moraine material as well as ice blocks, which melted to form kettleholes (ponds and lakes of Holocene time). Geologic, hydrologic, and geographic features combine to generate a broad array of wetland plant communities in the Bandy Ranch vicinity and the greater Ovando Valley.

The aquatic zone is well-developed in this complex with the deepest ponds having open water with submergent and floating aquatic macrophytes; communities present include Stuckenia pectinata - Myriophyllum sibiricum (sago pondweed - American water-milfoil), Nuphar polysepalum (yellow pondlily) and Zannichellia palustris (horned pondweed). Accessory species with high constancy in the first-named community include Ranunculus aquatilis (white water-buttercup), Ruppia islandica (ditch grass) and Utricularia vulgaris (common bladderwort). Marsh vegetation with emergent vegetation dominant occurs just above the aquatic zone occupying positions that are inundated for most of the growing season but will dry down in late summer or early autumn in most years; characteristic plant associations are Glyceria borealis (northern mannagrass), Typha latifolia (common cattail), Carex utriculata (beaked sedge), Carex atherodes (awned sedge) and Schoenoplectus acutus (hardstem bulrush). The drawdown zone, inundated in the early portion of the growing season and interposed between the drier meadow zone above and marsh zone below, may occupy the entire basin of temporary ponds; the most ubiquitous and extensive of drawdown communities is Eleocharis palustris (common spikerush) in which Eleocharis acicularis (needle spike-rush), Alopecurus aequalis (short-awn foxtail), Glyceria borealis (northern mannagrass), Sium suave (hemlock water-parsnip), and Polygonum amphibium (water smartweed, also minor representation as community type of same name) are the common herbs. Hordeum jubatum (foxtail barley) and Carex (= Carex lanuginosa, wooly sedge) communities occur in brackish water drawdown zones. The dominance of the Juncus balticus (Baltic rush) community in the driest of wetlands, subirrigated meadow vegetation, that lies between Festuca (fescue)-dominated uplands and seasonally inundated wetlands, is possibly indicative of historically intensive grazing; Deschampsia caespitosa (tufted hairgrass), Poa pratensis (Kentucky bluegrass) and Agrostis alba (redtop) are the common graminoids, often co-dominant with Juncus balticus. Characteristic meadow forbs include Potentilla anserina (common silverweed), Iris missouriensis (Rocky Mountain Iris), Symphyotrichum spathulatum (=Aster occidentalis, western aster) and Mentha arvensis (field mint).

The uplands are primarily productive grasslands dominated by the tussock formers Festuca campestris (rough fescue), Festuca idahoensis (Idaho fescue), Pseudoroegneria spicata (bluebunch wheatgrass), Koeleria macrantha (prairie junegrass), and Danthonia intermedia (timber oatgrass). Shrublands dominated by Artemisia tridentata ssp. vaseyana (mountain big sagebrush) or Artemisia tripartita (threetip 
sagebrush) and combinations of the above named grasses are also present, though having much less acreage than the grasslands.

\section{Key Environmental Factors}

The most significant factor determining vegetation differences and zonation is water regime, the length of time plants are inundated; water regime for most of the ponds and swales in this system is in turn determined by annual precipitation and groundwater recharge. Glacial till underlying this site is derived from the Monture Glacier, which has less limestone and is apparently associated with fresher water than other till-mantled sites in the greater Ovando Valley.

\section{Rarity}

The sensitive plant, Grindelia howellii (Howell's gumweed), is locally common in the meadow zone of many ponds in the Bandy area. The only animal species of concern sighting has been that of Canada lynx (Felis lynx). No sensitive plant communities have yet been recorded.

\section{Other Values}

At least 11 plant communities are found at this site which a relatively high degree of diversity for an area of limited extent. This area is part of the greater Ovando Valley, which is one of the three or four richest wetland areas in Montana in terms of absolute number of wetlands and wetland community diversity.

\section{Land Use}

Livestock grazing, primarily cattle, has historically occurred within this landscape and continues to the present. The Bandy Ranch is owned by the University of Montana School of Forestry and is used for research.

\section{Exotics}

This area has not been explicitly inventoried for exotics but in the course of community sampling Cirsium arvense (Canada thistle), Taraxacum officinale (common dandelion), Agrostis alba (redtop), Poa pratensis (Kentucky bluegrass) and Phleum pratense (timothy) were all identified as alien increasers threatening native diversity, primarily in the meadow zone; of the above only Cirsium is rated as noxious. Since the initial survey, Centaurea spp. (knapweed species) has become common in the upland grasslands and a few miles west of the site Euphorbia esula (leafy spurge) is abundant in disturbed grasslands and thus poses a potential threat.

\section{Uplands}

Cattle grazing occurs extensively on the uplands, but stock generally exhibit a preference for remaining in the proximity of wetlands.

\section{Information Needs}

The past grazing intensities and regimes need to be ascertained so that future impacts can be avoided or mitigated. It is also important to better understand the ecology and population biology of the rare Grindelia howellii (Howell's gumweed). Land use practices on the uplands, as they affect the embedded wetlands, need documentation.

\section{Management Needs}

A thorough weed survey, including an estimation of the contribution of alien and pasture grasses, is needed. Herbicides are currently being employed to control the Centaurea spp. populations however, the 
affects of this treatment on the native vegetation is currently unknown. The hydrology of the area needs documentation; especially testing the assumption that groundwater is contributed wholly from precipitation input into the immediate basin and also the hydrologic connectivity to the Blackfoot River.

\section{Source}

Cook, B. J. 2001. Temporary hydrologic connections make "isolated" wetlands function at the landscape scale. Ph.D. Dissertation. University of Montana, Missoula, Montana.

Lesica, P. 1994. The distribution of plant community diversity associated with glacial wetlands in the Ovando Valley, Montana. Unpublished termination report to The Nature Conservancy, Montana Field Office, Helena.

\section{Element Occurrence Information}

\begin{tabular}{lcc}
\hline & \multicolumn{2}{c}{ Rarity Ranks } \\
Plant Association / Dominance Type & State & Global \\
\hline Carex atherodes Herbaceous Vegetation & S3S5 & G3G5 \\
Carex pellita Herbaceous Vegetation & SP & G3G5 \\
Carex utriculata Herbaceous Vegetation & S5 & G5 \\
Eleocharis palustris Herbageuses Vegetation & S5 & G5 \\
Glyceria borealis Herbaceous Vegetation & S3 & G4 \\
Hordeum jubatum Herbaceous Vegetation & S4 & G4 \\
Juncus balticus Herbaceous Vegetation & S5 & G5 \\
Polygonum amphibium Permanently Flooded Herbaceous Vegetation & S? & G5 \\
Schoenoplectus acutus Herbaceous Vegetation & S5 & G5 \\
Stuckenia pectinata - Myriophyllum sibiricum Herbaceous Vegetation & S1Q & G3G4 \\
Typha latifolia Western Herbaceous Vegetation & S5 & G5 \\
Stuckenia pectinata - Zannichellia palustris Herbaceous Vegetation & S1Q & G3G4 \\
\hline
\end{tabular}




\section{Beaver Creek Wetlands Complex}

\section{Directions}

Portions of this site are located on private land and landowner permission is required to access these privately held areas. This wetland complex lies approximately 20 miles southeast of Malta and extends in a southeasterly trending arc another 14 miles. It is accessed via a road that branches, from State Route 191 on the southern outskirts of Malta, to the southeast. Take this road to the south-southeast for approximately 12.5 miles where it forks into two branches that ultimately lead to the eastern and western periphery of the wetland complex. There are a number of dirt roads that branch southward from the southeastern fork and access the heart of the complex (unimproved county roads in Phillips Co. at this writing are not named nor numbered on conventional surface ownership maps).

\section{Description}

This wetland occurs in the Northern Glaciated Plains and contains somewhat more than 50 shallow depressional wetlands from about 5 to 100 acres in extent. In this landscape a thin mantle of glacial outwash is distributed over marine shales and dense bentonitic clays; both substrates are moderately to highly impervious causing the depressions to hold water in the early portion of the growing season. Many of the shallow ponds have been dug out to provide stock water later in the season and to improve waterfowl habitat. Only four plant associations were identified for this extensive landscape; this low community diversity reflects the harsh edaphic environment and the paucity of permanent water in most of these shallow depressions. Occurring between the Artemisia tridentata ssp. wyomingensis / Pascopyrum smithii-dominated uplands and the drawdown zone is Pascopyrum smithii-Hordeum jubatum (western wheatgrass / foxtail barley), the most common wet meadow component of this landscape. Eleocharis acicularis (needle spikerush) and the small annual forbs Navarretia intertexta (needleleaf navarretia), Plantago elongata (slender plantain) and Veronica peregrina (purslane speedwell) are common in most stands. Iva axillaris - Rumex salicifolius (povertyweed - willow dock) occupies the broad, low gradient basins which are shallowly inundated in the spring and drawdown every year to reveal bottoms of gray bentonite. Both nominal species are strongly rhizomatous, though forming a sparse cover. The Eleocharis palustris (common spikerush) association is also within the drawdown zone but occurs on a different substrate where organic matter appears to be incorporated. Hordeum jubatum and Eleocharis acicularis are typically well represented in drier stands whereas Polygonum amphibium (water smartweed) co-dominance defines this type's wet extreme. Marsh vegetation, dominated by either the Schoenoplectus acutus (hardstem bulrush) or Schoenoplectus heterochaetus (slender bulrush) associations, typifies depressions sufficiently deep to remain permanently inundated during most years. Forbs commonly associated with these marsh communities include Polygonum amphibium, Eleocharis palustris and Callitriche heterophylla (twoheaded water-starwort).

Artemisia tridentata ssp. wyomingensis (Wyoming big sagebrush), Pascopyrum smithii (western wheatgrass), and Poa secunda (Sandberg's bluegrass) dominate the upland vegetation and form plant associations with various combinations of the above-listed species.

\section{Key Environmental Factors}

The fine-textured marine shales and bentonites act as sealants in the bottoms of depressions perching water until it is evapotranspired. These wetlands are thus principally dependent on winter and spring precipitation via surface flow as input. Hydroperiod, water depth and duration, is the primary driver of community composition with basin slope gradient determining the relative width of ecotones between associations. 


\section{Rarity}

Four plant species found in these wetlands are listed as being of concern by the Montana Natural Heritage Program. These include Bacopa rotundifolia (disk waterhyssop), Psilocarphus brevissimus (short woollyheads), Schoenoplectus heterochaetus (slender bulrush) and Plagiobothrys leptocladus (finebranched popcornflower). In addition, Spergularia marina (salt-marsh sandspurry), a diminutive annual collected only a few times in Montana, was observed in a number of pond margins. Neither the Iva axillaris - Rumex salicifolius drawdown community nor the Schoenoplectus heterochaeta marshland have been described elsewhere.

\section{Other Values}

Shorebird species find this valuable breeding habitat; among those observed were Recurvirostra americana (American avocets), Limosa fedoa (marbled godwit), Phalaropus tricolor (Wilson's phalarope), Cataptrophorus semipalmatus (willet) and Charadrius vociferous (killdeer).

\section{Land Use}

The whole of this site is managed for livestock. Some of the ponds have been enhanced for wildlife, particularly waterfowl production.

\section{Exotics}

Pernicious exotics do not occur in the area but some annual bromes (Bromus spp.) and Melilotus officinalis (yellow sweet clover) are present.

\section{Uplands}

This landscape has been historically grazed at varying intensities since the 1870 's.

\section{Information Needs}

The weed populations need to be inventoried. Past and continuing land use requires documentation. The hydrological consequences of pond modification, other than merely increased water depths, should be ascertained.

\section{Management Needs}

Once weeds/exotics are inventoried a management plan should be formulated.

\section{Source}

Lesica, P. 1998. Flora and vegetation associated with Beaver Creek Wetlands, Phillips County, Montana. Report submitted to The Nature Conservancy, Montana Field Office, Helena.

\section{Element Occurrence Information}

\begin{tabular}{lcc}
\hline & \multicolumn{2}{c}{ Rarity Ranks } \\
Plant Association / Dominance Type & State & Global \\
\hline Eleocharis palustris Herbaceous Vegetation & S5 & G5 \\
Iva axillaris - Rumex salicifolius Dominance Type & $*$ & $*$ \\
Pascopyrum smithii - Hordeum jubatum Herbaceous Vegetation & SP & G4 \\
Schoenoplectus acutus Herbaceous Vegetation & S5 & G5 \\
Schoenoplectus heterochaeta Dominance Type & $*$ & $*$ \\
\hline
\end{tabular}

* Rank not assigned 


\section{Bent Flat Fen}

\section{Directions}

From Hungary Horse, MT at the head of Hungary Horse Reservoir travel south around the lake on East Side Road to the confluence of the South Fork Flathead River and the Spotted Bear River. From the confluence take US Forest Road 568 to the east approximately 4.9 miles, where there is a turnoff to the north (in Section 11). Travel on foot northwest from this point for about one quarter mile to the peatland periphery.

\section{Description}

Bent Flat Fen is in the Flathead Range of northwestern Montana, about 4.2 air miles east of Spotted Bear Ranger Station. This site is in the lower drainage of the Spotted Bear River, about four miles above its confluence with the South Fork Flathead River. Bent Flat is the site of an extremely rich (calcium enriched waters) patterned fen, which encompasses about 10 to 12 acres. Patterned fens are a common type of peatland in boreal latitudes but are relatively uncommon in Montana and absent southward. The patterning results from series of distinctive elongated hummocks (strings) that project about 10 to $30 \mathrm{~cm}(2.5$ to 8 inches) above the mini-hollows (flarks); these features are oriented perpendicular to the topographic slope (i.e. features run across slope). Marl (calcium rich clays and silts) deposited from the fine-textured alluvium borne by inflowing seeps and steams, underlies both the strings and flarks. The vegetation composition reflects both the high water table and the calcium-rich substrates. The up-gradient portions of the fen are dominated by various spikerush species, including Eleocharis quinqueflora (=Eleocharis pauciflora, fewflower spikerush), Eleocharis rostellata (beaked spikerush), and Eleocharis tenuis (slender spikerush) and Schoenoplectus acutus (= Scirpus acutus, hardstem bulrush). Carex buxbaumii (Buxbaum's sedge) is also common. Dasiphora fruticosa v. floribunda (=Potentilla fruticosa, shrubby cinquefoil), Betula glandulosa (= Betula nana, bog birch), and scattered stunted Picea engelmannii (Engelmann spruce) are found on hummocks and are common on the lower part of the fen. The dominant hummock-forming moss is Tomentypnum nitens; other mosses documented include Aulacomnium palustre, Bryum pseudotriquetrum, Campylium stellatum, Limprichtia revolvens, and Scorpidium scorpioides. The paucity of Sphagnum species testifies to the fen's calcium-rich waters and its concomitantly high $\mathrm{pH}$ values.

\section{Key Environmental Factors}

This fen's calcium-rich water is supplied by seeps and springs on the slope immediately above; the quality and quantity of this supply is crucial to the maintenance of the fen.

\section{Rarity}

The most acclaimed feature of this site is the fact that it is a rich fen with well-developed string-flark patterning, a seldom seen attribute outside of more boreal climes. The six rare or sensitive plants documented from the site, Eleocharis rostellata, Carex livida (pale sedge), Cypripedium parviflorum ( $=C$. calceolus, lesser yellow lady's slipper), Drosera anglica (English sundew), Trichophorum caespitosum (= Scirpus caespitosus, tufted bulrush), and Scorpidium scorpioides, occur here due to the richness (high calcium concentrations) of the site.

\section{Other Values}

Protection measures to maintain the high quality of inflowing waters are recommended. 


\section{Land Use}

The boundary is constrained by the cutting units immediately to the north and east. The forest south of the peatland and north of Forest Road 568 has been thinned but forms a good buffer around the south side of the peatland. The site is within US Forest Service Management Area 13 where management emphasis is on producing quality deer and elk winter habitat.

\section{Exotics}

No exotics were recorded from the peatland proper.

\section{Uplands}

The uplands are merchantable forest of unknown composition. There has been no recent timber harvesting.

\section{Information Needs}

The setting of this site needs documentation, including the types of surrounding forest, the chemistry of waters incoming to the site, and the wetland plant communities occupying the site. Existing and potential threats also need investigation. Land use practices on the uplands, as they affect the embedded wetlands, need documentation.

\section{Management Needs}

An obvious measure would be to assure that the water source is maintained and protected, which could be most practicably achieved through a special designation, such as Botanical Area.

\section{Source}

Chadde, S. W., J. S. Shelly, R. J. Bursik, R. K. Moseley, A. G. Evenden, M. Mantas, F. Rabe, and B. Heidel. 1998. Peatlands on National Forests of the Northern Rocky Mountains: ecology and conservation. General Technical Report RMRS-GTR-11, U.S. Department of Agriculture, Forest Service, Rocky Mountain Research Station, Ogden, Utah.

\section{Element Occurrence Information}

\begin{tabular}{lcc}
\hline & \multicolumn{2}{c}{ Rarity Ranks } \\
Plant Association / Dominance Type & State & Global \\
\hline Betula nana / Mesic Forbs - Mesic Graminoids Shrubland & $*$ & $\mathrm{G} 3 \mathrm{G} 4$ \\
Carex buxbaumii Herbaceous Vegetation & $\mathrm{S} 3$ & $\mathrm{G} 3$ \\
Dasiphora fruticosa ssp. floribunda Shrubland & $*$ & $\mathrm{G} 5 ?$ \\
Eleocharis quinqueflora Herbaceous Vegetation & $\mathrm{S} 3$ & $\mathrm{G} 4$ \\
Eleocharis rostellata Herbaceous Vegetation & $\mathrm{S} 1$ & $*$ \\
Schoenoplectus acutus Herbaceous Vegetation & $\mathrm{S} 5$ & $\mathrm{G} 5$ \\
Trichophorum caespitosum - Carex livida Herbaceous Vegetation & $\mathrm{S} 5$ & $\mathrm{G} 5$ \\
\hline
\end{tabular}

* Rank not assigned 


\section{Blacktail Bench Wetlands Complex}

\section{Directions}

All land in this complex is located on the Blackfeet Indian Reservation. However, ownership could be either private individuals or the tribe or both; permission is required for access regardless. These wetlands lie approximately 18 air miles west-northwest of Dupuyer, MT between the two forks of Blacktail Creek in the foothills at the base of the Rocky Mountain Front Range. From Heart Butte take the Badger Creek Road south approximately 2.15 miles to BIA Road 107; travel southwesterly on BIA Road 107 about 1.2 miles bearing south at the first fork, continue to the 2 mile mark at which point the wetland complex begins and stretches in a southwesterly direction for 2 to 2.5 miles. There is a network of dirt roads that can be used to access all the scattered ponds of the wetland complex.

\section{Description}

The Blacktail Bench Complex lies wholly within subsection "a" (Rocky Mountain Front Foothills) of the Northwestern Glaciated Plains Section (331D). This approximately 2,500 acre landscape, which ranges from 4,750 to 4,900 feet in elevation, has been strongly modified by glaciation with the deposition of till, outwash, and alluvium and, most especially, the formation of kettleholes, from which 5-40 acre ponds have formed. Depending on the hydrologic regime and basin shape, the ponds may have as many as five or as few as two vegetation zones. The Blacktail Bench area is situated in the quaking aspen groveland, where Populus tremuloides (quaking aspen) stands are interspersed with ponds, graminoid-dominated swales and upland grasslands. The forested wetland fringes have the following wetland communities represented, usually as linear and small patches, on a gradient of increasing duration of flooding or saturation; Populus tremuloides - Populus balsamifera ssp. trichocarpa / Osmorhiza occidentalis (quaking aspen - black cottonwood / western sweet-cicely), Populus tremuloides / Cornus sericea (quaking aspen / red-osier dogwood), Populus balsamifera ssp. trichocarpa / Cornus sericea (black cottonwood / red-osier dogwood), Populus tremuloides / Calamagrostis canadensis (quaking aspen / bluejoint reedgrass). The only aquatic communities documented, Potamogeton richardsonii - Myriophyllum sibiricum (Richardson's pondweed - water milfoil) and Stuckenia pectinata - Myriophyllum sibiricum (fennel-leaved pondweed - water milfoil) occur in open water habitats ranging from fresh to brackish with increasing representation of Stuckenia pectinata indicating increasing water salinity. Emergent marsh communities, characterized as flooded through most of the growing season and occasionally yearlong, occur around pond margins (and the center of temporary ponds) and include Glyceria borealis - Eleocharis palustris (northern mannagrass - common spikerush), Eleocharis palustris - Eleocharis acicularis (common spikerush needle spikerush), and Schoenoplectus acutus (= Scirpus acutus, hardstem bulrush). The drawdown zone of this pond complex supports only two communities, Eleocharis palustris - Mentha arvensis (common spikerush - field mint) and Eleocharis palustris - Juncus balticus (common spikerush - Baltic rush). Potentilla anserina (silverweed), Polygonum amphibium (water smartweed), Symphyotrichum ciliolatus (=Aster brachyactis, alkali aster) and Scirpus americanus (American bulrush) constitute species commonly associated with drawdown zones of ponds in this vicinity. Graminoid-dominated meadow vegetation comprises the outermost wetland zone of these ponds with dominant communities Deschampsia caespitosa - Juncus balticus (tufted hairgrass - Baltic rush) and Deschampsia caespitosa - Carex pellita (tufted hairgrass - wooly sedge) with Mentha arvensis (field mint), Symphyotrichum ericoides var. pansum (=Aster pansus, white prairie aster), Poa juncifolia (alkali bluegrass), Carex praegracilis (clustered field sedge), and Elymus trachycaulus (bearded wheatgrass) occurring as common, occasionally dominant, associated species.

The forested uplands are primarily Populus tremuloides-dominated plant associations. The most common are Populus tremuloides / Symphoricarpos albus (quaking aspen / common snowberry) and Populus tremuloides / Calamagrostis rubescens (quaking aspen / pine grass); these deciduous forests are slowly 
being replaced by coniferous species. The grasslands are characterized by several associations dominated by Festuca campestris (rough fescue), Festuca idahoensis (Idaho fescue), Danthonia parryi (Parry's oatgrass) and Lupinus sericeus (silky lupine). Small patches of the shrub type Dasiphora fruticosa / Festuca campestris (shrubby cinquefoil / rough fescue) also occur scattered in mesic microsites.

\section{Key Environmental Factors}

To the degree these wetlands are maintained by groundwater recharge from the adjacent uplands, community zonation can be expected to fluctuate with climatic oscillations. It is also probable that regionally derived aquifers exist and interact with the locally derived component. The groundwater is relatively fresh with conductivity values ranging from 230 to $1,275 \mathrm{uhmos} / \mathrm{cm}$.

\section{Rarity}

Carex crawei (Craw's sedge), a sensitive plant species, was found at six wetlands in this complex. Potamogeton richardsonii - Myriophyllum sibiricum and Stuckenia pectinata - Myriophyllum sibiricum are both highly ranked, indicating that they are considered rare in Montana at this time but more information on their distribution is definitely required. To date they have been described only from information collected in western Montana. Several high quality, albeit of restricted size, examples of three relatively uncommon deciduous tree-dominated communities were noted, Populus tremuloides - Populus balsamifera ssp. trichocarpa / Osmorhiza occidentalis, Populus tremuloides / Calamagrostis canadensis, and Popu-

lus balsamifera ssp. trichocarpa / Cornus sericea. Both grizzly bear (Ursus arctos horribilis) and Canada lynx (Felis lynx) have been recorded from this complex; these wetlands are acknowledged to be critical grizzly bear spring habitat.

\section{Other Values}

The Blacktail Bench Wetland is one of the best examples of the aspen parkland / glacial pothole ecosystems found in the western U. S. There may be good examples in Canada, but many of their systems have been degraded by the introduction of non-native pasture grasses through grazing and sowing. This wetland complex is within the home range travels of grizzly bears and contains abundant spring and summer bear foods of high desirability. Source author ranks this as one of the two best wetland complexes of this nature to be found south of Canada.

\section{Land Use}

These lands are currently being grazed by cattle and are rated as being in fair to good condition.

\section{Exotics}

Cirsium arvense (Canada thistle), Sonchus (sow thistle) spp., Poa pratensis (Kentucky bluegrass) and Phleum pratense (timothy) and Poa palustris (fowl bluegrass) are locally common; in places Phleum pratense has become very dense, possibly due to past grazing practices.

\section{Uplands}

Cattle grazing occurs extensively on the uplands, but stock generally exhibit a preference for remaining in the proximity of wetlands.

\section{Information Needs}

The grazing history needs to be elucidated and the kind and extent of exotic plants needs inventory. 


\section{Management Needs}

A weed management plan needs to be instituted in both uplands and wetlands.

\section{Source}

Lesica, P. 1989. The vegetation and flora of glaciated prairie potholes on the Blackfeet Indian Reservation, Montana. Unpublished final report to Big Sky Field Office, The Nature Conservancy, Helena, MT.

\section{Element Occurrence Information}

\begin{tabular}{lcc}
\hline & \multicolumn{2}{c}{ Rarity Ranks } \\
Plant Association / Dominance Type & State & Global \\
\hline Deschampsia caespitosa - Carex pellita Dominance Type & $*$ & $*$ \\
Deschampsia caespitosa - Juncus balticus Dominance Type & $*$ & $*$ \\
Eleocharis palustris - Eleocharis acicularis Dominance Type & $*$ & $*$ \\
Eleocharis palustris - Juncus balticus Herbaceous Vegetation & $*$ & $*$ \\
Eleocharis palustris - Mentha arvensis Herbaceous Vegetation & $*$ & $*$ \\
Glyceria borealis - Eleocharis palustris Dominance Type & $*$ & $*$ \\
Populus balsamifera ssp. trichocarpa / Cornus sericea Forest & $\mathrm{S} 3 ?$ & $\mathrm{G} 3 ?$ \\
Populus tremuloides / Calamagrostis canadensis Forest & $\mathrm{S} 2$ & $\mathrm{G} 3$ \\
Populus tremuloides / Cornus sericea Forest & $\mathrm{S} 3$ & $\mathrm{G} 4$ \\
Populus tremuloides - Populus balsamifera ssp. trichocarpa / Osmorhiza occi- & & \\
dentalis Forest & $\mathrm{S} 2 \mathrm{Q}$ & $\mathrm{G} 2 \mathrm{Q}$ \\
Potamogeton richardsonii - Myriophyllum sibiricum Aquatic Vegetation & $\mathrm{S} 2 \mathrm{Q}$ & $\mathrm{G} 2 \mathrm{Q}$ \\
Schoenoplectus acutus Herbaceous Vegetation & $\mathrm{S} 5$ & $\mathrm{G} 5 ?$ \\
Stuckenia pectinata - Myriophyllum sibiricum Aquatic Vegetation & $\mathrm{S} 1 \mathrm{Q}$ & $\mathrm{G} 3 \mathrm{G} 4$ \\
\hline
\end{tabular}

* Rank not assigned 


\section{Cody Lake}

\section{Directions}

Lower Cody Lake is situated in a US Forest Service holding within the Purcell Mountains of northwestern Montana, about 15 air miles southeast of Libby. Lower Cody Lake is the lowest and largest of three ponds drained by Cody Creek, a tributary to the Fisher River. Travel east on State Highway 37 to the first bridge over the Kootenai River and then at the east end or the bridge turn south onto US Forest Road 530. Travel southward for 8 miles on Forest Road 530 until intersecting Forest Road 4596 (Cody Lakes Road). Travel east on Forest Road 4596 for approximately 7 miles to a point just below the lowermost Cody Lake. Hike east $50 \mathrm{~m}$ to pond and fen.

\section{Description}

Lower Cody Lake is the lowermost of three small ponds (1-2 acres) that occur near the headwaters of Cody Creek. Lower Cody Lake, elevation 4,700 feet $(1433 \mathrm{~m})$, is the most significant of the three since it contains a deep waterbody, up to 12 feet $(4 \mathrm{~m})$, fringed by a thick, floating, organic mat. A diversity of peatland shrubs, including Betula glandulosa (= Betula nana, bog birch), Salix candida (hoary willow), and Kalmia microphylla (small-leaved laurel) occur adjacent to the pond and ostensibly their cover is sufficient to define a number of plant associations. The major graminoids are Carex lasiocarpa (slender sedge), Carex utriculata (beaked sedge), Carex limosa (mud sedge), and Eleocharis quinqueflora (= Eleocharis pauciflora, few-flower spikerush); where each of these species is dominant it indicates a unique plant association. Menyanthes trifoliata (bog buckbean) is the most common forb. Mosses with the greatest cover include Tomentypnum nitens, various species of Sphagnum, Campylium stellatum, and Drepanocladus spp. Scorpidium scorpioides, a bryophyte indicative of calcium rich water, occurs adjacent to the pond.

Adjacent upland forests are dominated by Picea spp. (spruce), Larix occidentalis (western larch), and Pseudotsuga menziesii (Douglas-fir).

\section{Key Environmental Factors}

The current suite of peatland species is maintained by a relatively stable hydrologic regime in this partially closed pond basin.

\section{Rarity}

Three species rated sensitive by the Northern Region, US Forest Service are found in the peatland: Synaptomys borealis (Northern bog lemming), Eriophorum viridicarinatum (green-keeled cottongrass), and Scorpidium scorpioides (a moss found in calcium-rich environments).

\section{Other Values}

Cody Lake represents a high-quality example of a deep pond upon which an organic mat is encroaching, demonstrating the presumed course of natural succession on these types of habitat.

\section{Land Use}

Past anthropogenic disturbances to this site, if any, have not been noted, but the threat of future impacts are reduced by the Kootenai National Forest Plan of 1987 inclusion of this area in Management Area 13 (protected old-growth), where timber harvest is not allowed. 


\section{Exotics}

No exotics have yet been identified for this site.

\section{Uplands}

The surrounding uplands are under a reduced threat of timber harvest because of the Management Area 13 location, where the Kootenai National Forest Plan excludes timber cutting to protect old-growth.

\section{Information Needs}

Additional vascular and nonvascular floristic, weedy species, and vegetation surveys are needed. Land use practices on the uplands, as they affect the embedded wetlands, needs documentation.

\section{Management Needs}

The biological significance of this site has led to the U.S. Forest Service to consider it a Proposed Special Interest Area - Botanic as well as a Candidate Natural Area.

\section{Source}

Chadde, S. W., J. S. Shelly, R. J. Bursik, R. K. Moseley, A. G. Evenden, M. Mantas, F. Rabe, and B. Heidel. 1998. Peatlands on National Forests of the Northern Rocky Mountains: ecology and conservation. General Technical Report RMRS-GTR-11, U.S. Department of Agriculture, Forest Service, Rocky Mountain Research Station, Ogden, Utah.

\section{Element Occurrence Information}

\begin{tabular}{lcc}
\hline & \multicolumn{2}{c}{ Rarity Ranks } \\
Plant Association / Dominance Type & State & Global \\
\hline Betula glandulosa / Carex utriculata Shrubland & $\mathrm{S} 4$ & $\mathrm{G} 4 ?$ \\
Carex lasiocarpa Herbaceous Vegetation & $\mathrm{S} 4$ & $\mathrm{G} 4 ?$ \\
Carex limosa Herbaceous Vegetation & $\mathrm{S} 2$ & $\mathrm{G} 2$ \\
Carex utriculata Herbaceous Vegetation & $\mathrm{S} 5$ & $\mathrm{G} 5$ \\
Eleocharis quinqueflora Herbaceous Vegetation & $\mathrm{S} 3$ & $\mathrm{G} 4$ \\
Kalmia microphylla Dwarf-shrubland & $*$ & $*$ \\
Salix candida Dwarf-Shrubland & $*$ & $*$ \\
\hline
\end{tabular}

* Rank not assigned 


\section{Comertown East Wetlands}

\section{Directions}

A portion of this site is located on private land and consequently landowner permission is required to access that area. This wetland is located in extreme northeastern MT, about 6 air miles northwest of Westby, MT and just west of the McElroy County Road and east of North Star County Road. It is most conveniently accessed via McElroy Rd. which runs northward from State Route 5 about 3.6 miles west of Westby. Taking McElroy road 4 miles to the north will access the eastern perimeter of the wetland.

\section{Description}

This site contains rolling collapsed moraine topography exhibiting a diverse assemblage of wetland communities and intact uplands. It may include buried glacial meltwater channels, with groundwater movement and salt accumulations. The elevations and topographic relief diminish to east.

The uplands are characterized by mixed-grass prairie communities dominated by Elymus lanceolatus (thickspike wheatgrass), Koeleria macrantha (prairie junegrass), and Pascopyrum smithii (western wheatgrass) with Nassella viridula (green needlegrass), Bouteloua gracilis (blue grama), Hesperostipa comata (needle-and-thread), and Hesperostipa curtiseta (northern porcupine grass) occurring as common associates, depending on the moisture status of the site.

\section{Key Environmental Factors}

Perpetuation of this site's hydrology is critical but at this juncture the source of water to this wetland has not positively identified, but, almost certainly it is not confined to locally generated groundwater.

\section{Rarity}

Among animal species of concern, only piping plover (Charadrius melodus) has been sighted on this wetland complex. This is also the site of a high quality occurrence of Elymus lanceolatus (Koeleria macrantha, thickspike wheatgrass - prairie junegrass), a recently described and uncommon prairie grassland. No sensitive plant species have been located to date.

\section{Other Values}

This site includes one of the few large semi-permanent marshes in Sheridan County with intact upland borders. The area has high value as waterfowl breeding habitat. Boreal chorus frogs (Pseudacris maculata) and western chorus frogs (Pseudacris triseriata) were noted to be numerous.

\section{Land Use}

Virtually all of the land is used for grazing with a small portion of the more level adjacent uplands plowed.

\section{Exotics}

In an initial cursory survey no exotic species were noted.

\section{Uplands}

The impacts of livestock grazing or other land uses have not been determined at this time. 


\section{Information Needs}

This site's hydrology cannot be presumed secure until it is better understood. Local precipitation input could not possibly account for the volume of water filling the marshlands during spring maximum levels. The wetlands need explicitly to be targeted for survey since the initial botanical survey was cursory and focused on rare plant species and the grassland component. The zoological component, particularly grassland nesting birds, requires a concentrated effort.

\section{Management Needs}

Noxious weeds were not found in the initial survey but an intensive survey is needed, as well as a weed management plan if necessary.

\section{Source}

Field inventory records are on file with the Montana Natural Heritage Program.

\section{Element Occurrence Information}

No wetland community elements were explicitly documented from the site. 


\section{Comertown West Wetlands}

\section{Directions}

A portion of this site is located on private land; landowner permission is required to access that area. This site is located in the far northeastern corner of Sheridan County approximately 1.5 miles northwest of Comertown, MT. It is accessed by an unnamed county road that runs north from State Route 5 about 1.5 miles west of Westby, MT. The southeastern end of the wetland complex can be reached by driving north on the county road about one mile (crossing the railroad tracks). The complex can also be accessed at numerous points west of the North Westby County Road.

\section{Description}

Comertown West occupies a gently rolling collapsed glacial moraine covered with productive mixedgrass prairie plant associations that are unusually extensive and of high quality. Imbedded within the prairie is a large semi-permanent wetland with an exceptionally convoluted shoreline. The wetland communities were not described at the time of visitation, but it was recognized that there was considerable habitat diversity and numerous wetland types would be recognized including those dominated by Puccinellia nuttalliana (Nuttall's alkaligrass), Distichlis stricta (inland saltgrass), Carex praegracilis (clustered field sedge), Scirpus spp. (bulrush spp.), Eleocharis spp. (spikerush species), and Pascopyrum smithii (western wheatgrass) and potentially other species.

The upland area is dominated by mixed-grass prairie associations in which Elymus lanceolatus (thickspike wheatgrass), Pascopyrum smithii (western wheatgrass), Koeleria macrantha (prairie junegrass), Bouteloua gracilis (blue grama), Nassella viridula (green needlegrass) and Hesperostipa comata (needleand-thread) are the dominant grasses and the forb component is comparatively depauperate.

\section{Key Environmental Factors}

It is likely that the hydrology of this site is supported by a regional aquifer and not just input from local groundwaters. Paleochannels may be involved in delivery of groundwater to the extensive, and at times, relatively deep ephemeral pond. The upland is intact due to appropriate grazing in the past or to adequate time for recovery from heavy grazing pressure

\section{Rarity}

This is the site of a high quality occurrence of Elymus lanceolatus (Koeleria macrantha, thickspike wheatgrass - prairie junegrass), a recently described and uncommon prairie grassland. No sensitive animal or plant elements were documented as the result of one relatively cursory site visit.

\section{Other Values}

This area has outstanding waterfowl/shorebird breeding habitat.

\section{Land Use}

This site is leased for livestock grazing.

\section{Exotics}

No exotics were recorded during a general botanical inventory. 


\section{Uplands}

Upland land use practices that could impact wetlands have not been addressed.

\section{Information Needs}

The initial survey of this site was cursory but revealed that an intensive botanical, zoological and communities inventory would be worthwhile. Past and current grazing history and land use needs documentation to inform management prescriptions.

\section{Management Needs}

This concern cannot be adequately addressed until information needs have been satisfied; a weed inventory should be undertaken, followed by a weed management plan if necessary.

\section{Source}

Field inventory records are on file with the Montana Natural Heritage Program.

\section{Element Occurrence Information}

No wetland community elements were explicitly documented from the site. 


\section{Deer Park Wetlands Complex}

\section{Directions}

A portion of this site is located on private land; landowner permission is required to access that area. Powell County Rd. 102 branches to the north off State Route 200, between its junction with State Route 141 and Ovando. Take this county road to its junction with County Road 109 (approximately 5.1 miles from State Route 200). The junction of County Roads 102 and 109 is in the near vicinity of a number of private roads (old logging roads) that access the complex from its western fringe.

\section{Description}

This complex occupies a wide portion of the Blackfoot River Valley in the vicinity of the town of Ovando. The nearly stagnant piedmont glaciers of the latter Pleistocene Era occupied most of the area north of the river depositing large amounts of morainal material as well as ice blocks, which melted to form kettleholes (ponds and lakes of Holocene time). Geologic, hydrologic, and geographic features combine to generate a broad array of wetland plant communities in the greater Ovando Valley. The Deer Park wetland complex is in a higher precipitation regime located closer to the mountains and within a forested landscape compared to the other high-quality Ovando wetland complexes. Due to these factors the wetlands are comprised of primarily fresh water plant associations including five fresh water community types not found on other Ovando Valley wetland complexes. The aquatic zone is well developed with the deepest ponds containing open water habitat with submergent and floating aquatic macrophytes; communities present include Myriophyllum sibiricum (American water-milfoil), Nuphar lutea ssp. polysepala (yellow pondlily) and Zannichellia palustris (horned pondweed). Accessory species with high constancy in the Myriophyllum community include Ranunculus aquatilis (white water-buttercup), Ruppia islandica (ditch grass) and Utricularia vulgaris (common bladderwort). This wetland complex is unique among those in the greater Ovando complex due to the presence of peatlands, concentrations of organic soils with a water table that is maintained near the surface. The predominant vegetation type is characterized by (and named for) a relatively solid sward of Carex lasiocarpa (slender sedge) which also occurs under a thin canopy of Betula glandulosa (= Betula nana, bog birch) to yield the Betula glandulosa / Carex lasiocarpa shrub type. Another peatland shrub type of very limited distribution is Betula glandulosa / Calamagrostis canadensis (bog birch / bluejoint reedgrass). Carex limosa (mud sedge) is an uncommon peatland type associated with low $\mathrm{pH}$ fresh waters and deep organic soils.

Marsh vegetation with dominant emergent vegetation occurs just above the aquatic zone, occupying positions that are inundated for most of the growing season but dry down in late summer or early autumn in most years; characteristic plant associations are Glyceria borealis (northern mannagrass), Typha latifolia (common cattail), Carex utriculata (beaked sedge), Carex atherodes (awned sedge), Equisetum fluviatile (water horsetail) and Schoenoplectus acutus (hardstem bulrush). Of the marsh associations only Equisetum fluviatile occurs on an organic substrate. Common, often co-dominant, herbs in these marshes include Polygonum amphibium (water smartweed), Eleocharis palustris (common spike-rush), Sium suave (hemlock water-parsnip) and Potamogeton gramineus (grassy pondweed). The drawdown zone, inundated in the early portion of the growing season and interposed between the drier meadow zone above and the marsh zone below, is of very limited extent in the Deer Park complex; the only drawdown communitiy inventoried here was Eleocharis palustris (common spikerush). Eleocharis acicularis (needle spikerush), Alopecurus aequalis (short-awn foxtail), Glyceria borealis (northern mannagrass), Sium suave (hemlock water-parsnip), and Polygonum amphibium (water smartweed, also minor representation as community type of same name) are the common herbs.

Dry to mesic forests of Pseudotsuga menziesii (Douglas-fir), Pinus ponderosa (ponderosa pine), and Pinus contorta (lodgepole pine) constitute the matrix for the potholes and swales of this site. 


\section{Key Environmental Factors}

The most significant factor determining vegetation differences and zonation is hydro-period, the length of time plants are inundated. Water regime for most of the ponds and swales in this system is determined by groundwater seepage, which is dependent on recharge by annual precipitation.

\section{Rarity}

Two circumboreal sensitive plant species, Carex chordorrhiza (rope-root sedge) and Eriophorum viridicarinatum (green-keeled cottongrass), are found at the southern extreme of their distribution in the fens of the Deer Park complex. Utricularia intermedia (flatleaf bladderwort), an aquatic macrophyte considered a sensitive plant species, is reported from ponds in this complex. Four mammal species considered sensitive, North American wolverine (Gulo gulo luscus), Canada lynx (Felis lynx), grizzly bear (Ursus artos horribilis), and fisher (Martes pennati), have been spotted within the defined boundaries of this wetland complex.

\section{Other Values}

Within the Ovando Valley the Deer Park area contains more freshwater systems and communities than other wetland complexes. This area also supports peatlands, with at least three identified plant associations and three peatland plants of special concern. This part of the Ovando Valley is one of the three or four richest wetland areas in Montana in terms of absolute number of wetlands and wetland community diversity.

\section{Land Use}

Lands surrounding potholes and swales have been timbered to varying degrees; many of the stands are in the early successional stages. Livestock are run on rangelands but have not negatively impacted the wetlands at this time.

\section{Exotics}

This component was not explicitly noted in the source document.

\section{Uplands}

Cattle grazing occurs extensively on the uplands, but stock generally exhibit a preference for remaining in the proximity of wetlands.

\section{Information Needs}

The author of the report indicated that the communities of this site were not exhaustively inventoried or described. A thorough weed survey should be undertaken. The grazing history needs to be determined. The source of groundwater supplying this site should be determined although it appears to be topographically concentrated precipitation and unlikely tied to the river several hundred feet below. It would be of value to understand how timber harvest and road building affect the area's hydrology. Land use practices on the uplands, as they affect the embedded wetlands, need documentation.

\section{Management Needs}

Management needs are dependent on completion of information needs listed above. 


\section{Source}

Lesica, P. 1994. The distribution of plant community diversity associated with glacial wetlands in the Ovando Valley, Montana. Unpublished termination report to The Nature Conservancy, Montana Field Office, Helena.

\section{Element Occurrence Information}

\begin{tabular}{|c|c|c|}
\hline \multirow[b]{2}{*}{ Plant Association / Dominance Type } & \multicolumn{2}{|c|}{ Rarity Ranks } \\
\hline & State & Global \\
\hline Betula glandulosa / Carex lasiocarpa Shrubland & S4 & * \\
\hline Betula glandulosa / Calamagrostis canadensis Shrubland & $*$ & * \\
\hline Carex atherodes Herbaceous Vegetation & S3S5 & G3G5 \\
\hline Carex lasiocarpa Herbaceous Vegetation & $\mathrm{S} 4$ & G4? \\
\hline Carex limosa Herbaceous Vegetation & S2 & $\mathrm{G} 2$ \\
\hline Carex utriculata Herbaceous Vegetation & S5 & G5 \\
\hline Eleocharis palustris Herbaceous Vegetation & S5 & G5 \\
\hline Equisetum fluviatile Herbaceous Vegetation & S4 & G4 \\
\hline Glyceria borealis Herbaceous Vegetation & S3 & G4 \\
\hline Juncus balticus Herbaceous Vegetation & S5 & G5 \\
\hline Stuckenia pectinata - Myriophyllum sibiricum Herbaceous Vegetation & S1Q & G3G4 \\
\hline Nuphar lutea ssp. polysepala Herbaceous Vegetation & $\mathrm{S} ?$ & G5 \\
\hline Schoenoplectus acutus Herbaceous Vegetation & S5 & G5 \\
\hline Typha latifolia Western Herbaceous Vegetation & S5 & G5 \\
\hline
\end{tabular}

* Rank not assigned 


\section{Duck Lake Wetlands Complex}

\section{Directions}

All land in this complex is located on the Blackfeet Indian Reservation. Ownership could reside with private individuals, the tribe or both; permission is required for access regardless. This complex lies about four air miles east of Babb, MT and extends eastward another six miles. It extends northward from State Route 464 about 4 miles. It is most easily accessed by driving north from St. Mary to the Babb-Duck Lake Junction, turning east onto Route 464 and proceeding about 3.2 miles. At this point BIA Route 51 branches to the north accessing, through a myriad of dirt roads, this 8,000-acre plus parcel.

\section{Description}

This is a large complex comprised of herbaceous wetland, deciduous forest, and prairie occurring at elevations of 5,100 to 5,250 ft. It includes both Duck and Goose Lakes. This complex lies wholly within subsection "a" (Rocky Mountain Front Foothills) of the Northwestern Glaciated Plains Section (331D). The landscape has been strongly modified by glaciation with the deposition of till, drift, and alluvium and, most especially, by the formation of kettleholes, from which 5-80 acre ponds have formed. Depending on hydrologic regime and basin shape, the ponds may have as many as five or as few as two vegetation zones. The forested wetland fringes of the larger water bodies have the following wetland communities represented, usually as linear and small patches, on a gradient of increasing duration of flooding or saturation; Populus tremuloides - Populus balsamifera ssp. trichocarpa / Osmorhiza occidentalis (quaking aspen - black cottonwood / western sweet-cicely), Populus tremuloides / Cornus sericea (quaking aspen / red-osier dogwood), Populus balsamifera ssp. trichocarpa / Cornus sericea (black cottonwood / red-osier dogwood), Populus tremuloides / Calamagrostis canadensis (quaking aspen / bluejoint reedgrass). The Populus tremuloides-dominated stands support a highly variable amount of Populus balsamifera spp. trichocarpa, which tends not to reproduce as successsfully as $P$. tremuloides. Picea spp. (spruce) and Abies lasiocarpa (subalpine fir) occur scattered as well, but their recruitment to canopy positions is exceedingly slow. The only aquatic communities documented, Potamogeton richardsonii Myriophyllum sibiricum (Richardson's pondweed - water milfoil) and Stuckenia pectinatus (= Potamogeton pectinatus) - Myriophyllum sibiricum (fennel-leaved pondweed - water milfoil) occur in open water habitats ranging from fresh to brackish. Increasing representation of Stuckenia pectinatus indicates increasing water salinity.

A full range of emergent marsh communities, herb-dominated and flooded throughout most of the growing season and occasionally yearlong, occur in this complex around pond margins (and the centers of temporary ponds). These communities include Carex atherodes / Eleocharis palustris (awned sedge common spikerush), Carex utriculata - Eleocharis palustris (beaked sedge - common spikerush), Eleocharis palustris - Eleocharis acicularis (common spikerush - needle spikerush), Glyceria borealis Eleocharis palustris (northern mannagrass - common spikerush) and Schoenoplectus acutus (hardstem bulrush). Several small marshland patches noted but not sampled are nearly monospecifically dominated by Glyceria grandis (giant mannagrass) and Alopecurus aequalis (water foxtail). The drawdown zone of this pond complex is somewhat depauperate relative to that of other Blackfeet Indian Reservation complexes, including only Eleocharis palustris - Mentha arvensis (common spikerush / field mint) and Eleocharis palustris / Chenopodium glaucum (common spikerush / glaucus goosefoot) communities. Potentilla anserina (silverweed), Polygonum amphibium (water smartweed), Symphyotrichum ciliatum (=Aster brachyactis, alkali aster) and Scirpus americanus (American bulrush) constitute species commonly associated with drawdown zones of ponds in this vicinity. Graminoid-dominated meadow vegetation comprises the outermost wetland zone of these ponds with dominant communities being Deschampsia caespitosa - Juncus balticus (tufted hairgrass - Baltic rush) and a much lesser representation of Deschampsia caespitosa - Carex pellita (tufted hairgrass - wooly sedge) with Mentha arvensis (field mint), Symphyo- 
trichum ericoides var. pansum (=Aster pansus, white prairie aster), Poa juncifolia (alkali bluegrass), Carex praegracilis (clustered field sedge) and Elymus trachycaulus (bearded wheatgrass) as common, occasionally dominant, associated species.

The eastern portion of the complex is primarily high-quality grassland dominated by Festuca campestris (rough fescue), Festuca idahoensis (Idaho fescue), Achnatherum occidentale (western needlegrass) and Danthonia intermedia (timber oatgrass). In the western portion of the complex, drier parklands are Populus tremuloides-dominated with the common community types being Populus tremuloides / Symphoricarpos albus (quaking aspen / snowberry) and Populus tremuloides / Calamagrostis rubescens (quaking aspen / pine grass). Abies lasiocarpa (subalpine fir) and Picea engelmannii (including Engelmann spruce and its hybrids with Picea glauca, white spruce) and Pseudotsuga menziesii (Douglas-fir) are very scattered in both the uplands and wetland forested communities, indicating that succession is very slow to these more shade-tolerant species.

\section{Key Environmental Factors}

To the degree that these wetlands are maintained by groundwater recharge from the adjacent uplands, community zonation can be expected to fluctuate with climatic oscillations. It is also probable that regionally derived aquifers exist and interact with the locally derived component. Shallow ponds that dry up by late summer are probably dependent on near-surface groundwater. The impermeable nature of the substrate in the vicinity of this site is responsible for the perching of the water table.

\section{Rarity}

This site partially overlaps with the Goose Lake Grasslands Site (S.USMTHP*148), which was proposed to include high-quality upland grasslands, and harbors two state sensitive plant species, Botrychium hesperium (camomile grape-fern or western moonwort) and Ranunculus cardiophyllus (heartleaf buttercup), which are associated with moist to wet sites. The common loon (Gavia immer) has been noted on ponds of this complex. Sensitive mammal species recorded from this site include Canada lynx (Felis lynx) and grizzly bear (Ursus arctos horribilis). Carex sychnocephala (many-headed sedge) was associated with one pond in this area. Potamogeton richardsonii - Myriophyllum sibiricum and Stuckenia pectinata Myriophyllum sibiricum are both highly ranked communities, indicating that their status is considered rare in Montana at this time but, more information on their distribution is definitely required; to date they have been described from limited information collected in western Montana and the community has not yet been nominated for global ranking. Very similar types dominated by the Eurasian exotic Myriophyllum spicatum (Eurasian water-milfoil) have been described as common across the Midwest. No special status plants or animals were observed.

\section{Other Values}

This site is part of a larger complex of wetlands and native prairie found on the Blackfeet Indian Reservation, considered the best-condition and largest prairie pothole landscape in Montana. It is also possibly one of the best examples (highest quality, most extensive) of the aspen parkland / glacial pothole ecosystems found in the western U.S. The flora of this complex is rich and a broad diversity of plant associations are represented (relative to other glaciated wetland complexes). The whole of this complex, especially the moist to wet Populus tremuloides (quaking aspen) and Populus balsamifera ssp. trichocarpa (black cottonwood) dominated communities is critical spring and summer range for Ursus arctos horribilis (grizzly bear) due to an abundance of preferred food. Sufficient biological surveys have been conducted to know that the following rodent species occur within the complex: meadow vole (Microtus pennsylvanicus), weasel (Mustela erminea), western jumping mouse (Zapus princeps), and pocket gopher (Thomomys talpoides). 


\section{Land Use}

Livestock currently graze the entire area, however the Fescue-dominated communities, which predominate in the eastern portion of the area, appear to be in good to excellent condition whereas the western portion of the area has been intensively grazed and degraded. At least in the forested wetlands and uplands livestock have preferentially grazed and browsed many of the same species judged to have prime value for wildlife including forbs that comprise a major component of Ursus horribilis (grizzly bear) spring diet.

\section{Exotics}

The Populus tremuloides - Populus balsamifera ssp. trichocarpa parkland meadow communities adjacent to ponds have been invaded by Poa pratensis (Kentucky bluegrass), Phleum pratense (timothy), Alopecurus pratensis (meadow foxtail), Cirsium arvense (Canada thistle), Sonchus uliginosus (marsh sow-thistle); in addition to the species cited above for disturbed meadows, Urtica dioica (stinging nettle) and Ranunculus uncinatus (little buttercup) have increased markedly in the livestock impacted portions of the forested stands.

\section{Uplands}

Cattle grazing occurs extensively on the uplands, but stock generally exhibit a preference for remaining in the proximity of wetlands.

\section{Information Needs}

Hydrologic control of these wetlands is not well understood. The grazing history of this site needs to be documented; do past grazing practices account for the high coverage of exotic pasture grasses and weeds? What are the conflicts, both actual and potential, between domestic stock and wildlife, especially the grizzly bear. Land use practices on the uplands, as they affect the embedded wetlands, need documentation.

\section{Management Needs}

A management plan to inventory and control the noxious weeds and exotic pasture grasses should be developed.

\section{Source}

Lesica, P. 1989. The vegetation and flora of glaciated prairie potholes on the Blackfeet Indian Reservation, Montana. Unpublished final report to Big Sky Field Office, The Nature Conservancy, Helena, MT.

Lesica, P. 1993. Using plant community diversity in reserve design for pothole prairie on the Blackfeet Indian Reservation, Montana, USA. Biological Conservation 65: 69-75.

Cooper, S. V., and B. L. Heidel. 1997. Population status and ecology of trembling aspen and black cottonwood communities on the Blackfeet Indian Reservation. Montana Natural Heritage Program, Helena, MT. 


\section{Element Occurrence Information}

\begin{tabular}{lcc}
\hline & \multicolumn{2}{c}{ Rarity Ranks } \\
Plant Association / Dominance Type & State & Global \\
\hline Carex atherodes Herbaceous Vegetation & S3S5 & G3G5 \\
Carex utriculata Herbaceous Vegetation & S5 & G5 \\
Deschampsia caespitosa - Carex spp. Herbaceous Vegetation & $\mathrm{S} 4 \mathrm{Q}$ & $\mathrm{G} 4 \mathrm{Q}$ \\
Deschampsia caespitosa Herbaceous Vegetation & $\mathrm{S} 4$ & $\mathrm{G} 4$ \\
Eleocharis palustris / Chenopodium glaucum Dominance Type & $*$ & $*$ \\
Eleocharis palustris - Eleocharis acicularis Dominance Type & $*$ & $*$ \\
Eleocharis palustris - Mentha arvensis Dominance Type & $*$ & $*$ \\
Glyceria borealis Herbaceous Vegetation & $\mathrm{S} 3$ & $\mathrm{G} 4$ \\
Populus balsamifera ssp. trichocarpa / Cornus sericea Forest & $\mathrm{S} 3 ?$ & $\mathrm{G} 3 ?$ \\
Populus tremuloides / Calamagrostis canadensis Forest & $\mathrm{S} 2$ & $\mathrm{G} 3$ \\
Populus tremuloides / Cornus sericea Forest & $\mathrm{S} 3$ & $\mathrm{G} 4$ \\
Populus tremuloides - Populus balsamifera ssp. trichocarpa / Osmorhiza occiden- & & \\
talis Forest & $\mathrm{S} 2 \mathrm{Q}$ & $\mathrm{G} 2 \mathrm{Q}$ \\
Potamogeton richardsonii - Myriophyllum sibiricum Aquatic Vegetation. & $\mathrm{S} 2 \mathrm{Q}$ & $\mathrm{G} 2 \mathrm{Q}$ \\
Schoenoplectus acutus Herbaceous Vegetation & $\mathrm{S} 5$ & $\mathrm{G} 5$ \\
Stuckenia pectinata - Myriophyllum sibiricum Aquatic Vegetation & $\mathrm{S} 1 \mathrm{Q}$ & $\mathrm{G} 3 \mathrm{G} 4$ \\
\hline
\end{tabular}

* Rank not assigned 


\section{East Glacier Wetlands Complex}

\section{Directions}

All land in this complex is located on the Blackfeet Indian Reservation. Ownership could reside with private individuals, the tribe or both; permission is required for access regardless. From the intersection of State Route 89 and Heart Butte Road just south of Browning, MT, travel south on Heart Butte Road approximately 5 miles. At this point an unmarked dirt road travels westerly to eventually intersect State Route 2; the first 4 miles of this dirt road traverses a complex of permanent and ephemeral ponds and wet swales.

\section{Description}

The 6,500 acre East Glacier Complex lies wholly within subsection "a" (Rocky Mountain Front Foothills) of the Northwestern Glaciated Plains Section (331D). This landscape has been strongly modified by glaciation with the deposition of till, outwash, and alluvium and, most especially, the formation of kettleholes, from which 5 to 100 acre ponds have formed. Depending on hydrologic regime and basin shape, the ponds may have as many as five or as few as two vegetation zones. The only aquatic communities documented, Potamogeton richardsonii - Myriophyllum sibiricum (Richardson's pondweed - water milfoil) and Stuckenia pectinatus (= Potamogeton pectinatus) - Myriophyllum sibiricum (fennel-leaved pondweed - water milfoil) occur in open water habitats ranging from fresh to brackish. Increasing representation of Stuckenia pectinata indicates increasing water salinity. Emergent marsh communities, flooded through most of the growing season and occasionally yearlong, occur around pond margins (and the center of temporary ponds) and include Carex utriculata - Eleocharis palustris (beaked sedge - common spikerush), Eleocharis palustris - Eleocharis acicularis (common spikerush - needle spikerush), and Schoenoplectus acutus (hardstem bulrush). The drawdown zone of this pond complex includes Eleocharis palustris - Hordeum jubatum (common spikerush - squirreltail barley), Distichlis spicata - Puccinellia spp. (inland saltgrass - alkaligrass species), Hordeum jubatum - Puccinellia spp. (squirreltail barley alkaligrass species), and Eleocharis palustris / Chenopodium glaucum (common spikerush / glaucus goosefoot); Potentilla anserina (silverweed), Polygonum amphibium (water smartweed), Symphyotrichum ciliolatus (=Aster brachyactis, alkali aster) and Scirpus americanus (American bulrush) constitute species commonly associated with drawdown zones of ponds in this vicinity. Graminoid-dominated meadow vegetation comprises the outermost wetland zone of these ponds with dominant communities of Deschampsia caespitosa - Juncus balticus (tufted hairgrass - Baltic rush) and Deschampsia caespitosa Carex pellita (tufted hairgrass - wooly sedge). Mentha arvensis (field mint), Symphyotrichum ericoides var. pansum (=Aster pansus, white prairie aster), Poa juncifolia (alkali bluegrass), Carex praegracilis (clustered field sedge) and Elymus trachycaulus (bearded wheatgrass) are common and occasionally dominant associated meadow species.

The wetlands are set in a complex mosaic of grasslands with Festuca campestris (rough fescue), Festuca idahoensis (Idaho fescue), Danthonia parryi (Parry's oatgrass) and Carex duriuscula (narrow-leaved sedge) being the dominant graminoids.

\section{Key Environmental Factors}

Water input at the surface, primarily as winter snowpack meltwater from surrounding basin slopes, and groundwater are the primary factors maintaining the ponds and vegetation communities. A partially permeable to impermeable substrate is crucial to maintaining a perched water table. Pond water in this complex is classed as fresh to brackish with conductivity ranging from 265 to $20,115 \mathrm{uhmos} / \mathrm{cm}$. 


\section{Rarity}

No special status plants or animals were observed. Potamogeton richardsonii - Myriophyllum sibiricum and Stuckenia pectinata - Myriophyllum sibiricum are both highly ranked, indicating that their status is considered rare in Montana at this time, but more information on their distribution is required since they have been described from limited information collected in western Montana and these communities have not yet been nominated for global ranking. Very similar types dominated by the Eurasian exotic Myriophyllum spicatum (Eurasian water-milfoil) have been described as common across the Midwest.

\section{Other Values}

This site is part of a larger complex of wetlands and undegraded native prairie found on the Blackfeet Indian Reservation that is hypothesized to be the highest quality and most extensive of those remaining in the Northern Great Plains of the United States. Of the eight areas studied on the Reservation, this area had the highest wetland plant community diversity. These wetlands are undoubtedly important nesting and staging areas for waterfowl and shorebirds. The flora of this complex is rich and exhibits a very high biological diversity due to the close proximity of many types of grassland, woodland, forest and wetlands.

\section{Land Use}

Livestock currently graze this area but the Fescue-dominated communities appear to be in good to excellent condition; livestock impact on wetlands areas was not addressed.

\section{Exotics}

No noxious weeds and only two pasture grasses, Poa pratensis (Kentucky bluegrass) and Phleum pratense (timothy) were noted in the description of this complex.

\section{Uplands}

Cattle grazing occurs extensively on the uplands, but stock generally exhibit a preference for remaining in the proximity of wetlands.

\section{Information Needs}

It is important to understand the hydrologic controls on these wetlands. The good to excellent condition noted for the upland grasslands would seem to indicate a lack of exotics but this needs to be established by intensive survey. The past grazing history should be documented so that the existing good quality conditions it has fostered can be implemented in the future.

\section{Management Needs}

These needs cannot be established until an exotic plant survey is conducted and the range condition is assessed.

\section{Source}

Lesica, P. 1989. The vegetation and flora of glaciated prairie potholes on the Blackfeet Indian Reservation, Montana. Unpublished final report to Big Sky Field Office, The Nature Conservancy, Helena, MT.

Lesica, P. 1993. Using plant community diversity in reserve design for pothole prairie on the Blackfeet Indian Reservation, Montana, USA. Biological Conservation 65: 69-75.

Lesica, P. 1993. East Glacier Pothole Prairie Preserve Design Package. Unpublished report to The Nature Conservancy, Helena, MT. 


\section{Element Occurrence Information}

\begin{tabular}{lcc}
\hline & \multicolumn{2}{c}{ Rarity Ranks } \\
Plant Association / Dominance Type & State & Global \\
\hline Carex utriculata Herbaceous Vegetation & $\mathrm{S} 5$ & $\mathrm{G} 5$ \\
Deschampsia caespitosa - Carex spp. Herbaceous Vegetation & $\mathrm{S} 4 \mathrm{Q}$ & $\mathrm{G} 4 \mathrm{Q}$ \\
Deschampsia caespitosa Herbaceous Vegetation & $\mathrm{S} 4$ & $\mathrm{G} 4$ \\
Distichlis spicata - Puccinellia nuttalliana - Distichlis spicata-Hordeum juba- & & \\
tum - Suaeda calceoliformis Herbaceous Vegetation & $\mathrm{S} ?$ & $\mathrm{G} 2 \mathrm{G} 3$ \\
Eleocharis palustris / Chenopodium glaucum Dominance Type & $*$ & $*$ \\
Eleocharis palustris Herbaceous Vegetation & $\mathrm{S} 5$ & $\mathrm{G} 5$ \\
Eleocharis palustris - Hordeum jubatum Dominance Type & $*$ & $*$ \\
Eleocharis palustris - Juncus alpinus Dominance Type & $*$ & $*$ \\
Hordeum jubatum Herbaceous Vegetation & $\mathrm{S} 4$ & $\mathrm{G} 4$ \\
Potamogeton richardsonii - Myriophyllum sibiricum Herbaceous Vegetation & $\mathrm{S} 2 \mathrm{Q}$ & $\mathrm{G} 2 \mathrm{Q}$ \\
Schoenoplectus acutus Herbaceous Vegetation & $\mathrm{S} 5$ & $\mathrm{G} 5$ \\
Stuckenia pectinata - Myriophyllum sibiricum Herbaceous Vegetation & $\mathrm{S} 1 \mathrm{Q}$ & $\mathrm{G} 3 \mathrm{G} 4$ \\
\hline
\end{tabular}

* Rank not assigned 


\section{East Hardscrabble Creek Wetlands}

\section{Directions}

From Culbertson, MT where State Highway 16 intersects U.S. Route 2 bear south to the Missouri River. From the bridge over the Missouri River take State Highway 16 southward for 6.5 miles to its intersection with County Road 335. Bear west on the county road for approximately $0.5 \mathrm{mi}$. and then south for another 0.5 miles at which point County Road 146 branches to the west. Take this west-bearing county road about 2.5 miles to its crossing of Hardscrabble Creek. The site lies south of County Road 146, stretching along the banks of Hardscrabble Creek.

\section{Description}

This $20+$ acre site at 2020 feet elevation is a broad, nearly level subirrigated meadow along Hardscrabble Creek. The soils are largely derived from coarse-textured alluvial deposits weathered from sandstone. Salt efflorescence, indicating alkaline conditions, is common across this alluvial flat. Only one plant community, Juncus balticus (Baltic rush) Herbaceous Vegetation, is explicitly stated to occupy this site, but from the data reported several more could be hypothesized to exist, albeit as mere fragments, probably including Pascopyrum smithii (western wheatgrass) Alluvial Flat Herbaceous Vegetation, Carex praegracilis (clustered field sedge) Herbaceous Vegetation, Eleocharis palustris (common spikerush) and Puccinellia nuttalliana (Nuttall's alkaligrass) Herbaceous Vegetation. There could also be some Puccinellia nuttalliana and Distichlis spicata (inland saltgrass) and Distichlis spicata - Hordeum jubatum - Puccinellia nuttalliana - Suaeda calceoliformis Herbaceous Vegetation communities.

\section{Key Environmental Factors}

The site is obviously subirrigated by the waters from Hardscrabble Creek. These water carry dissolved salts that are then deposited in this meadow with continued evapotranspiration of surface water.

\section{Rarity}

No sensitive species were noted at the time of the initial visit.

\section{Other Values}

No other values have been identified at this time.

\section{Land Use}

At the time of the June visit cattle were present and the results of past use were evident in cattle trails.

\section{Exotics}

"Relatively few exotic" species were noted but these have not been specified. It can be deduced from the species list to include some Chenopods but no noxious weeds.

\section{Uplands}

Cattle grazing has historically been a part of this landscape, though its impacts on the uplands have not been documented.

\section{Information Needs}

The context of this site needs to be established so that threats can be assessed. Though the condition was rated as good due to lack of exotics/weeds based on cursory inspection, there needs to be a formal survey 
for these threats. The grazing regime also needs to be documented, as more intensive use could be extremely destructive.

\section{Management Needs}

Many sites like this have been plowed and planted to "more productive" graminoids, this would obviously have serious consequences. If cattle use is to continue, information is needed on the optimal time of use and stocking numbers.

\section{Source}

Site Survey Summary Form; 23 June, 1988 filed by Peter Lesica, consulting ecologist, Missoula, MT.

\section{Element Occurrence Information}

\begin{tabular}{|c|c|c|}
\hline \multirow[b]{2}{*}{ Plant Association / Dominance Type } & \multicolumn{2}{|c|}{ Rarity Ranks } \\
\hline & State & Global \\
\hline Carex praegracilis Herbaceous Vegetation & S3S4 & G3G4 \\
\hline Distichlis spicata Herbaceous Vegetation & $\mathrm{S} 4$ & G5 \\
\hline Eleocharis palustris Herbaceous Vegetation & S5 & G5 \\
\hline Juncus balticus Herbaceous Vegetation & S5 & G5 \\
\hline Pascopyrum smithii Herbaceous Vegetation & S4 & G3G5Q \\
\hline Puccinellia nuttalliana Herbaceous Vegetation & S? & G3? \\
\hline
\end{tabular}




\section{Flatiron Bench Wetlands Complex}

\section{Directions}

All land in this complex is located on the Blackfeet Indian Reservation. Ownership could reside with private individuals, the tribe or both; permission is required for land access regardless. Travel west on State Route 49 approximately 5 to 5.5 miles from the intersection of State Route 2 and State Route 49 (Browning to Kiowa Junction Rd.) on the west side of Browning, MT, The major portion of this wetland complex, which covers 1,800 acres, lies immediately south of Route 49 between Willow Creek to the east and large aspen groves to the west.

\section{Description}

The Flatiron Bench Wetland Complex lies wholly within subsection "a" (Rocky Mountain Front Foothills) of the Northwestern Glaciated Plains Section (331D). This landscape has been strongly modified by glaciation with the deposition of till, outwash, and alluvium and, most especially, the formation of kettleholes, from which 5 to 20 acre ponds have formed. Depending on hydrologic regime and basin shape, the ponds may have as many as five or as few as two vegetation zones. The only aquatic community documented is from open water habitats, Potamogeton richardsonii / Myriophyllum sibiricum (Richardson's pondweed / water milfoil; these two indicator species, in addition to Stuckenia pectinatus (= Potamogeton pectinatus, fennel-leaved pondweed) dominate these ponds with fresh to slightly brackish water.

Emergent marsh communities, flooded through most of the growing season and occasionally yearlong, occur around pond margins (and the centers of temporary ponds) and include Glyceria borealis - Eleocharis palustris (northern mannagrass - common spikerush), Carex utriculata - Eleocharis palustris (beaked sedge - common spikerush), Eleocharis palustris - Eleocharis acicularis (common spikerush needle spikerush), and Scirpus acutus (hardstem bulrush). The drawdown zone of this pond complex includes Eleocharis palustris - Mentha arvensis (common spikerush / field mint), Eleocharis palustris Juncus alpinus (common spikerush - northern rush), Eleocharis palustris - Hordeum jubatum (common spikerush - squirreltail barley), and Distichlis spicata - Puccinellia spp. (inland saltgrass - alkaligrass species). Potentilla anserina (silverweed), Polygonum amphibium (water smartweed), Chenopodium glaucum (glaucus goosefoot) and Schoenoplectus americanus (American bulrush) constitute species commonly associated with drawdown zones of ponds in this vicinity. Graminoid-dominated meadow vegetation comprises the outermost wetland zone of these ponds with dominant communities Deschampsia caespitosa - Juncus balticus (tufted hairgrass - Baltic rush) and Deschampsia caespitosa - Carex pellita (tufted hairgrass - wooly sedge) with Mentha arvensis (field mint), Symphyotrichum ericoides var. pansum (=Aster pansus, white prairie aster), Poa juncifolia (alkali bluegrass), Carex praegracilis (clustered field sedge) and Elymus trachycaulus (bearded wheatgrass) common and occasionally dominant associated species. Near the head of Flatiron Creek is a Betula/Salix/Carex (birch / willow / coarse sedge) carr and fen complex with deep peat soils. At least a portion of the Populus tremuloides (trembling aspen) dominated groves fit the description of the Populus tremuloides / Osmorhiza occidentalis association which encompasses at least a wetland fringe.

The wetlands are set in a complex mosaic of grasslands with Festuca campestris (rough fescue), Festuca idahoensis (Idaho fescue), Danthonia parryi (Parry's oatgrass) and Carex duriuscula (narrow-leaved sedge) the dominant graminoids.

\section{Key Environmental Factors}

Wetland hydrology may be controlled by locally derived shallow groundwater, more regionally derived aquifers, or a combination of the two. Shallow ponds that dry up by late summer are likely dependent on 
a shallow groundwater source. However, other ponds in this complex are deeper, less ephemeral, and more likely to depend on groundwater originating from outside their local basins. Peatlands are usually formed under a non-fluctuating hydrologic regime, so the fen is probably receiving water from more regional aquifers. Pond water in this complex is fresh to slightly brackish with conductivity ranging from 320 to $1,660 \mathrm{uhmos} / \mathrm{cm}$.

\section{Rarity}

Highly ranked occurrences (A and B categories) of five sensitive plant species, Salix serissima (autumn willow), Gentianopsis macounii (Macoun's gentian), Carex livida (pale sedge), Eriophorum viridicarinatum (green-keeled cottongrass), Antennaria pulcherrima (showy pussytoes) are found within the Flatiron Mire Site (S.USMTHP*70), an exhaustively inventoried site contained within and occurring on the westernmost portion of the Flatiron Bench Wetland Complex. The first two listed species, as well as the sensitive Trichophorum pumilum (= Scirpus pumilus (Rolland's bulrush) and the mosses Scorpidium scorpioides and Meesia triquetra are associated with the fen portion of the wetlands. Carex sychnocephala (many-headed sedge) was found around one pond. Potamogeton richardsonii - Myriophyllum sibiricum, an aquatic community type, has been highly ranked, however, there are questions regarding its classification, both in the species synonymy of Myriophyllum and the extent to which this vegetation type has been inventoried. No animal species of concern have been reported to date.

\section{Other Values}

This site is part of a larger complex of wetlands and undegraded native prairie found on the Blackfeet Indian Reservation that is hypothesized to be the highest quality and most extensive of those remaining in the Northern Great Plains of the United States. This wetland complex is undoubtedly an important nesting and staging area for waterfowl and shorebirds. This site and the immediate vicinity have not been grazed for 15 years and provide excellent habitat for beavers and ungulates. The flora of this complex is rich and the overall biological diversity is high due to the close association of many types of grassland, woodland, forest, and wetlands.

\section{Land Use}

Part of this site was owned by Bob Scriver, who discontinued livestock grazing (except horses) in the early 1970's. The Nature Conservancy purchased the Scriver property in 2000 and is reportedly in the process of conveying it to the newly created Blackfeet Land Trust. Livestock currently graze a portion of this area but the Fescue-dominated communities appear to be in good condition; livestock impact on wetlands areas was not addressed.

\section{Exotics}

Cirsium arvense (Canada thistle) is common in the wet meadow zone around some of the ponds. Phleum pratense (timothy) is widespread in many of the swales but only occasional in the wet meadows associated with the ponds. Sonchus arvensis ssp. uliginosus (= Sonchus uliginosus, marsh sowthistle) is also reported for this area. The mire portion of this wetland at the time of first inventory (90-09-05) had no exotics.

\section{Uplands}

There is little evidence of human disturbance, confined to one small dump site, with no grazing for approximately 15 years. 


\section{Information Needs}

It is important to understand the hydrologic controls on the wetlands. The effect of climatic fluctuations and past grazing regimes needs to be determined. The Flatiron Mire has been thoroughly inventoried but the remainder of the wetland complex would benefit from an in-depth exploration. Land use practices on the uplands, as they affect the embedded wetlands, need documentation.

\section{Management Needs}

A management plan to control the noxious weeds at the site should be developed; stopping the incursion and expansion of non-native graminoids should be considered as well.

\section{Source}

Lesica, P. 1989. The vegetation and flora of glaciated prairie potholes on the Blackfeet Indian Reservation, Montana. Unpublished final report to Big Sky Field Office, The Nature Conservancy, Helena, MT.

Lesica, P. 1993. Using plant community diversity in reserve design for pothole prairie on the Blackfeet Indian Reservation, Montana, USA. Biological Conservation 65: 69-75.

Lesica, P. 1990. Flatiron Creek Wetlands Preserve Design Package. Unpublished report to The Nature Conservancy, Helena, MT.

\section{Element Occurrence Information}

\begin{tabular}{lcc}
\hline & \multicolumn{2}{c}{ Rarity Ranks } \\
Plant Association / Dominance Type & State & Global \\
\hline Carex utriculata Herbaceous Vegetation & $\mathrm{S} 5$ & $\mathrm{G} 5$ \\
Deschampsia caespitosa - Carex spp. Herbaceous Vegetation & $\mathrm{S} 4 \mathrm{Q}$ & $\mathrm{G} 4 \mathrm{Q}$ \\
Deschampsia caespitosa Herbaceous Vegetation & $\mathrm{S} 4$ & $\mathrm{G} 4$ \\
Distichlis spicata - Hordeum jubatum - Puccinellia nuttalliana - Suaeda calceoli- & & \\
formis Herbaceous Vegetation & $\mathrm{S} ?$ & $\mathrm{G} 2 \mathrm{G} 3$ \\
Eleocharis palustris - Eleocharis acicularis Dominance Type & $*$ & $*$ \\
Eleocharis palustris - Hordeum jubatum Dominance Type & $*$ & $*$ \\
Eleocharis palustris - Juncus alpinus Dominance Type & $*$ & $*$ \\
Glyceria borealis Herbaceous Vegetation & $\mathrm{S} 3$ & $\mathrm{G} 4$ \\
Potamogeton richardsonii - Myriophyllum sibiricum Aquatic Vegetation & $\mathrm{S} 2 \mathrm{Q}$ & $\mathrm{G} 2 \mathrm{Q}$ \\
Schoenoplectus acutus Herbaceous Vegetation & $\mathrm{S} 5$ & $\mathrm{G} 5$ \\
\hline$*$ Ran & &
\end{tabular}

* Rank not assigned 


\section{Hahnkamp Island}

\section{Directions}

On the frontage road proceed south $0.7 \mathrm{mi}$. from Melrose, MT and the park. Ford the Big Hole River to Hahnkamp Island, the whole of which constitutes the site.

\section{Description}

The Hahnkamp Island site is a comparatively flat island of gravelly and sandy alluvium in the main current of the Big Hole River. Relatively xeric habitat is found on the slightly raised interior of the island with vegetation including Artemisia tridentata / Pascopyrum smithii (big sagebrush / western wheatgrass) and Pascopyrum smithii-dominated grasslands. Edges of the island support an extensive, relatively highcondition Populus balsamifera ssp. trichocarpa / Cornus sericeus (black cottonwood / red osier dogwood) community interspersed with a Phalaris arundinacea community. A number of Salix (willow) dominated communities are also documented.

The higher areas near the center of the island support Artemisia tridentata (ssp. unknown) / Pascopyrum smithii (big sagebrush / western wheatgrass) shrubland and Pascopyrum smithii-dominated grassland.

\section{Key Environmental Factors}

This site is subject to the fluvial processes operating within this reach of the Big Hole River. Exceptional flood events are responsible for creating conditions conducive to the establishment of black cottonwood, but seedlings are sensitive to over-browsing by cattle.

\section{Rarity}

Muhlenbergia minutissima (annual muhly) a sensitive plant species is reported from this site. Populus balsamifera ssp. trichocarpa / Cornus sericeus is a common riparian community type, but one that has been highly impacted by browsing both by native ungulates and cattle, therefore, this occurrence, which is not truly high quality, still stands out as exceptional.

\section{Other Values}

High quality riparian wildlife habitat is provided by this site.

\section{Land Use}

This site has primarily been used for livestock production.

\section{Exotics}

Poa pratensis (Kentucky bluegrass) is abundant in many of the more moist sites. Bromus inermis (smooth brome) is sporadically distributed as is the noxious weed Cirsium arvense (Canada thistle), though both were noted to constitute relatively dense populations in several patches.

\section{Uplands}

Cattle and wild ungulates frequent the uplands, intensively browsing the palatable shrubs (for example Amelanchier alnifolia, serviceberry), but long-term impacts are unknown. Other anthropogenic influences are not documented. 


\section{Information Needs}

The locations of Muhlenbergia minutissima should be recorded with geographic positioning systems. Cattle and native ungulate use needs documentation to assure it doesn't conflict with cottonwood establishment and health of the native communities.

\section{Management Needs}

A sufficient pool of native species exists such that recovery of the site could be accomplished with the cessation of the intensive grazing/browsing. It should be ascertained how much of this pressure is due to native ungulates and how their impact might be reduced as well.

\section{Source}

Field inventory records are on file with the Montana Natural Heritage Program.

\section{Element Occurrence Information}

\begin{tabular}{lcc}
\hline & \multicolumn{2}{c}{ Rarity Ranks } \\
\cline { 2 - 3 } Plant Association / Dominance Type & State & Global \\
\hline Pascopyrum smithii Herbaceous Vegetation & S4 & G3G5Q \\
Phalaris arundinacea Herbaceous Vegetation & S4 & G5 \\
Populus balsamifera ssp. trichocarpa / Cornus sericea Forest & S3? & G3? \\
Salix spp. Shrub Communities & na & na \\
\hline
\end{tabular}




\section{Harkness Lakes Wetlands Complex}

\section{Directions}

Harkness Lake Wetlands are found along Cottonwood Creek in the east-slope foothills of the Beaverhead Range approximately 24 air-miles southwest of Lima, Montana. From Dell, Montana take Big Sheep Creek Rd. (USFS Road \#302) westward approximately 14.5 miles to the intersection of USFS Roads 325 and 326; take Road 326 to the south-southwest 9.8 miles where Nicholia Creek branches from Tendoy Creek. At the second branching of Road 326 take the right fork (more westerly) and proceed about 2.6 miles to the glacial pothole complex.

\section{Description}

This approximately 200 acre wetland complex occurs as a cluster of glacial potholes on a broad toeslope at 8,200 to 8,500 feet elevation and includes expansive wet meadows along Cottonwood Creek at the area's west end. Valley glaciers with their source in the high peaks of the Beaverhead Range created the pothole topography. Areas with a consistently high water table experience constant anaerobic conditions promoting the development of fen or carr vegetation and peat accumulation. Carex aquatilis -

Deschampsia caespitosa (water sedge - tufted hairgrass) is characteristic of relatively dry fen vegetation with peaty soils; in addition to the dominant species, Carex simulata (short-beaked sedge) is a codominant, with Potentilla gracilis (slender cinquefoil) and Symphyotrichum spathulatum (=Aster occidentalis, western aster) present as conspicuous forbs. Deeper waters with peat substrates have Carex utriculataCarex aquatilis (beaked sedge - water sedge) with Juncus balticus (Baltic rush) possibly codominant. Carex simulata and Carex aquatilis form dominant communities of the same names below springs, often on floating peat mats in shallow depressions. Eleocharis pauciflora (few-flowered spike-rush) commonly occurs with Ranunculus natans (floating water-buttercup) in the water-filled depressions. Carr vegetation exemplified by Salix wolfii / Carex aquatilis (Wolf's willow / water sedge) also develops on saturated peat in the shallow depressions below springs; Salix geyeriana (Geyer's willow) and Dasiphora fruticosa ssp. floribunda (shrubby cinquefoil) can occur as shrub-layer co-dominants. Juncus balticus and Carex simulata are consistently present but lack the cover of the dominant graminoid, Carex aquatilis.

Areas with greater water table fluctuations experience periodic aerobic conditions, which limits peat accumulation; these soils support wet meadow vegetation. Deschampsia caespitosa-Juncus balticus (tufted hairgrass / Baltic rush) occupies the driest meadows still considered wetlands; Carex petasata (Liddon's sedge) and Poa pratensis (Kentucky bluegrass) may, along with the nominal species, dominate the graminoid component. Disturbance by animals or livestock has resulted in higher forb cover than normally found; those with the greatest cover are Fragaria virginiana (Virginia strawberry), Potentilla diversifolia (diverse-leaved cinquefoil), and Taraxacum officinale (common dandelion). Along Cottonwood Creek silty soils with a high organic content support Poa secunda / Aster occidentalis (Sandberg's bluegrass / western aster); this community is dominated by and was originally named for Poa nevadensis (Nevada bluegrass) which has been amalgamated into the Poa secunda complex. Common graminoids are Poa cusickii (Cusick's bluegrass) and Hordeum brachyantherum (meadow barley). Forbs with the greatest cover include Symphyotrichum spathulatum, Potentilla gracilis (slender cinquefoil), and Taraxacum officinale. The vegetation adjacent to fens is often dominated by Dasiphora fruticosa ssp. floribunda / Deschampsia caespitosa with Salix geyeriana (Geyer's willow) consistently present with low coverage. Deschampsia caespitosa is the dominant graminoid with Carex aquatilis and Juncus balticus also occurring in high coverages; the substantial presence of Carex aquatilis and organic soils indicate this community has a hydrologic regime between fen and meadow (and might be better considered as Dasiphora fruticosa ssp. floribunda / Carex spp.). Potentilla diversifolia and Symphyotrichum spathulatum are common forbs. 
This wetland complex is in an upland matrix of shrub-steppe vegetation dominated by Artemisia tridentata ssp. vaseyana (mountain big sagebrush) and Festuca idahoensis (Idaho fescue).

\section{Key Environmental Factors}

Water is supplied to these wetlands by local snowmelt, groundwater (including that associated with Cottonwood Creek), and springs; the primary driving factor of community composition is the hydrologic regime, i.e. how much the water table fluctuates during the growing season. Stable water tables at or near the surface lead to peatlands, small fluctuation with moderately deep water cause marsh vegetation to develop, large fluctuations yield drawdown vegetation. Waters are near neutral with low dissolved solids and probably nutrient poor due to its percolation through Paleozoic quartzite, the predominant parent material across the wetland.

\section{Rarity}

Two formerly sensitive plant species, Agoseris lackschewitzii (pink Agoseris) and Gentiana aquatica (wet meadow gentian), and one currently listed species, Carex parryana ssp. idahoa (Idaho sedge), are associated with these wetlands. No rare community types or sensitive animal species have been identified for these wetlands.

\section{Other Values}

These high-quality fens, carrs and wet meadows are a source of biological diversity in an expansive semiarid shrub-steppe. Though the condition of this complex is relatively good, there have been hydrological alterations that, with mitigation, might be reversed to increase ecological diversity and restore the system to a more natural state. Wilson phalaropes (Phalaropes tricolor) were observed breeding in the wetlands in 1990 .

\section{Land Use}

Artificial streams connecting various wetlands in the complex have undoubtedly altered the drawdown regime of the ponds, decreasing the area of emergent vegetation in favor of more open water. Construction of a dam and headgate at Lower Harkness Lake has deepened the lake. Livestock have historically grazed this area and the drier wetland communities reflect their impacts in altered composition, hummocking and soil compaction.

\section{Exotics}

No noxious weeds were found in the wetland area, but exotic herbs Taraxacum officinale (common dandelion) and Poa pratensis (Kentucky bluegrass) have proliferated in many of the meadows as the result of past livestock grazing.

\section{Uplands}

There have been no observations on how local upland practices impact the wetland resource.

\section{Information Needs}

The security and source of the water input to this system should be ascertained so that interruption does not occur. Useful information would include how water diversions have altered the hydrology of the site. The past grazing regime needs to be documented. Land use practices on the uplands, as they affect the embedded wetlands, need documentation. 


\section{Management Needs}

Water input into the wetland needs to be maintained. Reversal of alterations to the hydrology could be evaluated; abandonment of some of the diversions could help preserve biological diversity values. The nature and intensity of the past grazing regime needs to be determined so that exotic pasture grasses and forbs are not favored over native species.

\section{Source}

Lesica, P. 1990. IVegetation and sensitive vascular plants of Morrison Lake, Harkness Lakes and Nicholia Creek wetlands, Beaverhead County, Montana. Termination report to Beaverhead National Forest, Dillon, Montana.

\section{Element Occurrence Information}

\begin{tabular}{|c|c|c|}
\hline \multirow[b]{2}{*}{ Plant Association / Dominance Type } & \multicolumn{2}{|c|}{ Rarity Ranks } \\
\hline & State & Global \\
\hline Carex aquatilis Herbaceous Vegetation & S4 & G5 \\
\hline Carex simulata Herbaceous Vegetation & S3 & G4 \\
\hline Carex utriculata Herbaceous Vegetation & S5 & G5 \\
\hline Dasiphora fruticosa ssp. floribunda / Deschampsia caespitosa Shrubland & S4 & G4 \\
\hline Deschampsia caespitosa Herbaceous Vegetation & S4 & G4 \\
\hline Poa secunda / Symphyotrichum spathulatum Dominance Type & $*$ & $*$ \\
\hline Salix wolfii / Carex aquatilis Shrubland & S3 & G4 \\
\hline
\end{tabular}

* Rank not assigned 


\section{Joiner Coulee Prairie Potholes}

\section{Directions}

This prairie pothole landscape is located on the Phillips and Blain County line approximately 14 air miles north of Dodson, MT on primarily private land (permission is required for access) and partly lands administered by the Bureau of Land Management, with inclusions of state lands as well. East from Dodson on U. S. Highway 2 take the first county road that bears to the north, cross Dodson Creek and continue for 12.25 miles then make a 90 degree turn to the west. Travel an additional 1.75 miles west and then bear north for 3 miles, placing one just inside the easternmost portion of the site. From here a secondary dirt road bears northwest accessing the northern portion of the site.

\section{Description}

Even though much of Montana north of the Missouri River has experienced continental glaciation, concentrations of prairie potholes generated from water-filled kettle holes are comparatively uncommon. The existence of a prairie pothole complex with its upland ecosystem still intact (unplowed) is quite unusual, however this site is an example. This is an area of gently rolling mixed-grass plains sprinkled with small and intermediate-sized ephemeral and semi-permanent ponds and marshes. Since most of the Joiner Coulee ponds are relatively shallow a well-developed marsh zone is generally not present. Wetland vegetation is very similar among the ponds. The drawdown zone (flooded in spring, dry by early summer) is dominated by Hordeum jubatum (squirrel-tail barley), Eleocharis palustris (common spikerush), Alopecurus aequalis (shortawn foxtail), Polygonum amphibium (water smartweed), Potentilla paradoxa (bushy or paradox cinquefoil) and Rumex crispus (curly dock). Some ponds support a poorly developed shallow marsh zone dominated by Eleocharis palustris, Polygonum amphibium, Eleocharis acicularis (needle spikerush), and Sagittaria cuneata (wapato). The open water zone of ponds with relatively permanent water is dominated by Myriophyllum sibiricum (= Myriophyllum spicatum, shortspike watermilfoil), Ranunculus aquatilis (water buttercup), Potamogeton richardsonii (Richardson's pondweed), and Stuckenia pectinatus (= Potamogeton pectinatus, sago pondweed).

The mixed-grass prairie of this landscape is dominated by Pascopyrum smithii (western wheatgrass), with an admixture of Hesperostipa comata (= Stipa comata, needle-and-thread) on coarser textured sites and widely fluctuating amounts of Bouteloua gracilis (blue grama), Koeleria macrantha (= Koeleria cristata, prairie junegrass), and Carex filifolia (threadleaf sedge). The presence of Nassella viridula (green needlegrass) indicates sites with slightly more favorable moisture status. Common forbs include Artemisia frigida (fringed sagewort, also considered a subshrub), Gutierrezia sarothrae (broom snakeweed), Heterotheca villosa (Chrysopsis villosa, hairy false goldenaster), Sphaeralcea coccinea (scarlet globemallow), Artemisia ludoviciana (western mugwort), and Antennaria rosea (= Antennaria microphylla (rosy pussytoes). In general these grasslands are in good condition, but a high cover of Selaginella densa (dense clubmoss) indicates where grazing has been abusive.

\section{Key Environmental Factors}

These ponds and sloughs are dependent upon surface runoff and groundwater for their water supply, which in turn is determined by annual precipitation. Because of cycles of drought and precipitation above normal, a concomitant wide variation in composition and extent of various vegetation zones can be expected.

\section{Rarity}

Two plant species considered rare in Montana are found in the area. Psilocarphus brevissimus (dwarf woolyheads) occurs in shallow, vernally flooded depressions. Elodea longivaginata (long-sheath water- 
weed) is known in Montana only from Liberty and Phillips Counties and occurs in at least one pond in the Joiner Coulee complex.

\section{Other Values}

The wetlands of this site are less diverse with less floristic diversity than those to the west in Glacier and Toole Counties and those to the east in Sheridan County; however this site putatively represents the best remaining example of native prairie pothole ecosystem in north-central Montana.

\section{Land Use}

Livestock grazing is currently the predominant land use.

\section{Exotics}

Exotics have not been accurately surveyed as yet. There is a cursory note to indicate that Agropyron cristatum (crested wheatgrass) has been introduced in the landscape and has become common.

\section{Uplands}

Cattle grazing occurs extensively on the uplands, but stock generally exhibit a preference for remaining in the proximity of wetlands.

\section{Information Needs}

Grazing history should be established along with an inventory of exotics, particularly noxious weeds. In general, land use practices on the uplands, as they affect the embedded wetlands, need documentation. Since the initial survey was conducted Euphorbia esula (leafy spurge) has become a major threat throughout this landscape and its extent in the wetland needs to be ascertained.

\section{Management Needs}

Livestock grazing should be carefully managed to protect the condition of the grasslands and wetlands and to protect the waterfowl and other bird nesting habitat within the site.

\section{Source}

Lesica, P. 1988. Joiner Coulee Pothole Prairie. Report to The Nature Conservancy, Helena, MT

Element Occurrence Information

\begin{tabular}{|c|c|c|}
\hline \multirow[b]{2}{*}{ Plant Association / Dominance Type } & \multicolumn{2}{|c|}{ Rarity Ranks } \\
\hline & State & Global \\
\hline Alopecurus aequalis Dominance Type & * & * \\
\hline Eleocharis palustris Herbaceous Vegetation & S5 & G5 \\
\hline Hordeum jubatum Herbaceous Vegetation & S4 & G4 \\
\hline Potamogeton richardsonii - Myriophyllum sibiricum Herbaceous Vegetation & S2Q & G2Q \\
\hline Stuckenia pectinatus - Myriophyllum sibiricum Herbaceous Vegetation & S1Q & G3G4 \\
\hline
\end{tabular}

* Rank not assigned 


\section{Kleinschmidt Lake Wetlands Complex}

\section{Directions}

A portion of this site is located on private land; landowner permission is required to enter that area. This extensive wetland complex can be accessed on its western side by driving to Ovando on State Route 200 and proceeding southward on Powell County Rd. for approximately 7 miles to the junction of County Rd. 112. This junction is in the southwestern portion of the complex. The eastern portion can be accessed by turning onto Powell County Rd. 112 from State Route 200 (see sign for Browns Lake fishing access) and proceeding about 3.2 miles south- southwest just past the southernmost lobe of Browns Lake, placing one in the southeast portion of the complex.

\section{Description}

This complex of ponds and wetlands occupies a wide portion of the Blackfoot River Valley southeast of the town of Ovando. The major landowner of the ponds is the U. S Fish and Wildlife Service; other landowners exhibit a broad array of conservation concern and include the Geary brothers, Steve Gravelly, the Jacobsen Ranch and an out-of-state party. The nearly stagnant piedmont glaciers of the latter Pleistocene Era occupied most of the area north of the Blackfoot River and deposited large amounts of morainal material and ice blocks, which melted to form kettleholes (ponds and lakes of Holocene time). Geologic, hydrologic, and geographic features combine to generate a broad array of wetland plant communities in the greater Ovando Valley, but the Kleinschmidt area is unique in exhibiting the greatest concentration of brackish waters with the highest degree of salinity, as measured by conductivity.

The aquatic zone is apparently not well developed in this complex with the deepest ponds having only two open water with submergent and floating aquatic macrophytes communities represented, Stuckenia pectinata - Myriophyllum sibiricum (sago pondweed - American water-milfoil) and Stuckenia pectinata Ruppia maritima (sago pondweed - beaked ditch-grass). Other species with high constancy in these communities include Ranunculus aquatilis (white water-buttercup), Ruppia islandica (ditch grass) and Utricularia vulgaris (common bladderwort).

Marsh vegetation with dominant emergent vegetation occurs just above the aquatic zone, occupying positions that are inundated for most of the growing season, but dry down in late summer or early autumn of most years. Characteristic plant associations are Typha latifolia (common cattail), Schoenoplectus maritimus (alkali bulrush), Schoenoplectus acutus (hardstem bulrush) and Hippuris vulgaris (mare's tail). Herbs commonly associated include Potentilla palustris (purple cinquifoil), Ranunculus gmelinii (small yellow water-buttercup), and Sium suave (hemlock water-parsnip). Notably absent are marsh communities (Carex utriculata (beaked sedge) and Carex atherodes (awned sedge) that are associated with fresh to mildly brackish water. The drawdown zone, inundated in the early portion of the growing season and interposed between the drier meadow zone above and marsh zone below, may occupy the entire basin of temporary ponds. The most ubiquitous and extensive of drawdown communities is Eleocharis palustris (common spike-rush) where Eleocharis acicularis (needle spike-rush), Alopecurus aequalis (short-awn foxtail), Glyceria borealis (northern mannagrass), Sium suave (hemlock water-parsnip), and Polygonum amphibium (water smartweed, also minor representation as community type of same name) are the common herbs. Hordeum jubatum (foxtail barley), Carex pellita (= Carex lanuginosa, wooly sedge), and Distichlis spicata (inland saltgrass) communities occur in the brackish water drawdown zone; the Distichlis community characterizes the most saline sites and supports such saline-indicative species as Puccinellia distans (weeping alkaligrass) and Salicornia rubra (red glasswort). A Juncus balticus (Baltic rush) community is dominant in sub-irrigated meadows, the driest of wetlands between Festuca (fescue)dominated uplands and seasonally inundated wetlands and is indicative of historically intensive grazing. Deschampsia caespitosa (tufted hairgrass), Poa pratensis (Kentucky bluegrass) and Agrostis alba (red- 
top) are the common graminoids and often co-dominant with Juncus balticus. Characteristic meadow forbs include Potentilla anserina (common silverweed), Iris missouriensis (Rocky Mountain Iris), Symphyotrichum spathulatum (=Aster occidentalis, western aster) and Mentha arvensis (field mint). The Poa secunda (Sandberg bluegrass, formerly Poa nevadensis) community, extensive only in the Kleinschmidt area and associated with greater salinity than Juncus balticus, is a type not described elsewhere in Montana. Associated graminoids include Carex praegracilis (clustered field sedge) and Poa pratensis (Kentucky bluegrass) with common forbs Potentilla anserina (common silverweed) and Antennaria microphylla (rosy pussy-toes).

The uplands are primarily productive grasslands dominated by the tussock formers Festuca campestris (rough fescue), Festuca idahoensis (Idaho fescue), Pseudoroegneria spicata (bluebunch wheatgrass) and Koeleria macrantha (prairie junegrass) and Danthonia intermedia (timber oatgrass). Shrublands dominated by Artemisia tridentata ssp. vaseyana (mountain big sagebrush) or Artemisia tripartita (threetip sagebrush) with combinations of the above grasses are also present, though comprising much less acreage than the grasslands.

\section{Key Environmental Factors}

The most significant factor determining vegetation differences and zonation is water regime, the length of time and depth to which plants are inundated. The water regime for most of the ponds and swales is determined by annual precipitation and groundwater chemistry. Groundwater chemistry and the brackishness of pond water are determined by the nature of underlying glacial till. The North Fork Blackfoot Glacier deposited more limestone in this vicinity resulting in more brackish water here than typical elsewhere.

\section{Rarity}

Hutchinsia procumbens (Hutchinsia), common in drawdown zone of two shallow ponds, Senecio debilis (Rocky Mountain ragwort), uncommon in meadow zones of three ponds, and Phlox missoulensis ( $=P$. kelseyi var. missoulensis, Missoula phlox) are the only sensitive plant species documented from this complex. Two bird species of concern, common loon (Gavia immer) and Columbian sharp-tailed grouse (Tympanuchus phasianellus columbianus) frequent this wetlands complex. Two mammal species of concern, North American wolverine (Gulo gulo luscus) and Canada lynx (Felis lynx) have been recorded within the boundaries of this wetland complex.

\section{Other Values}

This area is unique in the greater Ovando Valley for having a preponderance of brackish wetlands and at least one community type, Poa secunda (Sandberg's bluegrass, the taxonomic entity formerly known as Poa juncifolia, which is associated with saline environments and brackish waters) not documented beyond the state. The following animal species have been recorded within the wetland complex boundaries in the course of biological surveys and general observations: white-tailed jackrabbit (Lepus townsendii), Columbia spotted-frog (Rana luteiventris), deer mouse (Peromyscus maniculatus), montane vole (Microtus montanus), meadow vole (Microtus pennsylvanicus), yellow-pine chipmunk (Tamias amoenus), and western jumping mouse (Zapus princeps). This part of the Ovando Valley is one of the three or four richest wetland areas in Montana in terms of absolute number of wetlands and wetland community diversity.

\section{Land Use}

Livestock grazing has historically occurred on all the properties within this complex. The U. S. Fish and Wildlife Service owns a portion of this site to protect and enhance waterfowl and wildlife habitat. 


\section{Exotics}

Taraxacum officinale (common dandelion) and Poa pratensis (Kentucky bluegrass) were the only exotics documented from this area, though a thorough inventory would almost certainly reveal more.

\section{Uplands}

Cattle grazing occurs extensively on the uplands, but livestock generally exhibit a preference for remaining in the proximity of wetlands.

\section{Information Needs}

This area encompassed some private lands that were not inventoried for sensitive species, communities, or weed populations. The disturbance history of these wetlands remains undocumented. Land use practices on the uplands, as they affect the embedded wetlands, need documentation as well.

\section{Management Needs}

A comprehensive weed management plan should be developed that spans the various ownerships represented.

\section{Source}

Lesica, P. 1994. The distribution of plant community diversity associated with glacial wetlands in the Ovando Valley, Montana. Unpublished termination report to The Nature Conservancy, Montana Field Office, Helena.

\section{Element Occurrence Information}

\begin{tabular}{lcc}
\hline & \multicolumn{2}{c}{ Rarity Ranks } \\
Plant Association / Dominance Type & State & Global \\
\hline Carex pellita Herbaceous Vegetation & $\mathrm{S} 3 ?$ & $\mathrm{G} 3$ \\
Distichlis spicata Herbaceous Vegetation & $\mathrm{S} 4$ & $\mathrm{G} 5$ \\
Eleocharis palustris Herbaceous Vegetation & $\mathrm{S} 5$ & $\mathrm{G} 5$ \\
Hippuris vulgaris Herbaceous Vegetation & $*$ & $*$ \\
Hordeum jubatum Herbaceous Vegetation & $\mathrm{S} 4$ & $\mathrm{G} 4$ \\
Juncus balticus Herbaceous Vegetation & $\mathrm{S} 5$ & $\mathrm{G} 5$ \\
Schoenoplectus acutus Herbaceous Vegetation & $\mathrm{S} 5$ & $\mathrm{G} 5$ \\
Schoenoplectus maritimus Herbaceous Vegetation & $\mathrm{S} 4$ & $\mathrm{G} 4$ \\
Stuckenia pectinata - Myriophyllum sibiricum Herbaceous Vegetation & $\mathrm{S} 2 \mathrm{Q}$ & $\mathrm{G} 2 ?$ \\
Stuckenia pectinata - Ruppia maritima Herbaceous Vegetation & $\mathrm{S} ?$ & $*$ \\
Typha latifolia Western Herbaceous Vegetation & $\mathrm{S} 5$ & $\mathrm{G} 5$ \\
\hline
\end{tabular}

* Rank not assigned 


\section{Lazy Creek Swamp}

\section{Directions}

This site is most conveniently accessed from Whitefish, MT by taking the road to Big Mountain Ski Area, passing the ski area turn-off and continuing around Whitefish Lake until the pavement ends. Cross Brush Creek and continue past the open meadows and then turn right after Lazy Creek and continue to house at the road's end. Park and take trail on the south side of Lazy Creek to the site.

\section{Description}

This site is subirrigated yearlong by the waters of Lazy Creek to such an extent that soils are somewhat anoxic with appreciable organic matter buildup. The ground is flooded in the spring and saturated to the surface in mid-summer. Because of the constantly high water table the sole canopy dominant is Picea engelmannii (Engelmann spruce), which is shallowly rooted and is commonly windthrown. The undergrowth in the lowest portions of the landscape is dominated by Lysichiton americanus (American skunk cabbage); slightly elevated microsites also support lesser coverage of Lysichiton americanus and may be dominated by Equisetum arvense (scouring rush).

\section{Key Environmental Factors}

This site is maintained by dependably high spring flows in Lazy Creek and a constantly high water table throughout the year.

\section{Rarity}

Most of the site is occupied by a relatively high quality example of the Picea engelmannii / Lysichiton americanus (Engelmann spruce / skunk cabbage) plant association. The surrounding terrain supports Eriophorum viridicarinatum (thinleaf cottongrass), a plant species of potential concern. Three mammal species of concern have been recorded within the site boundaries including Canada lynx (Felis lynx), gray wolf (Canis lupus), and grizzly bear (Ursus arctos horribilis).

\section{Other Values}

The plant association found at this site is relatively uncommon. Since it occurs at lower elevations it is exposed to considerable threats from second home developments and livestock trespass (which can create a hummocked condition).

\section{Land Use}

This site occurs on Plum Creek Corporation and Montana State Forest lands that are managed for timber production. There has been firewood cutting at margins of the site, but no further anthropogenic disturbance has been noted. If wholesale timber extraction occurs by clearcutting or overstory removal, impact to the site's hydrologic regime could be expected, most likely causing the water table height to rise.

\section{Exotics}

Small populations of the noxious weed, Cirsium arvense (Canada thistle), occur at margins of the site.

\section{Uplands}

The composition of the uplands has not been detailed, but it is coniferous second-growth forest composed of merchantable species that are currently being logged. 


\section{Information Needs}

Is the nearby logging activity responsible for windthrow on the site itself? Factors, such as the composition and condition of the immediately surrounding landscape, need to be examined for information that would help determine the optimum width of a buffer strip around the primary site.

\section{Management Needs}

When final site boundaries have been defined, a buffer strip should be established to minimize impacts to the wetlands.

\section{Source}

Field inventory records are on file with the Montana Natural Heritage Program.

\section{Element Occurrence Information}

\begin{tabular}{lcc}
\hline & \multicolumn{2}{c}{ Rarity Ranks } \\
Plant Association / Dominance Type & State & Global \\
\hline Picea engelmannii / Lysichiton americanus Forest & S2 & G2 \\
\hline
\end{tabular}




\section{Leonard Creek Fen}

\section{Directions}

Leonard Creek Fen is located in southwestern Montana at the southern end of the Tobacco Root Mountains. The town of Ennis lies 11 miles $(18 \mathrm{~km})$ to the southeast. From the Madison Ranger District Station drive north 7.1 miles to McAllister and Meadow Creek Road (Forest Road 1221). Travel west on Road 12218 miles to Forest Road 1224. Travel north on Road 1224 about one mile to a road entering on the left. Take this fork about $1 / 2$ mile past a sedge meadow on the road's west side and park about 500 feet south of the meadow where the road turns to the west. Hike south-southeast approximately 500 feet to the north edge of the fen. The fen occurs at the head of a tributary to Leonard Creek.

\section{Description}

Leonard Creek Fen is found at 7,720 feet $(2201 \mathrm{~m})$ in a four-acre $(1.6 \mathrm{ha})$ basin with a floating organic mat. The primary peat-forming species, Sphagnum magellanicum, forms sphagnum moss lawns and small hummocks across the floating mat. Another moss, Drepanocladus capillifolius, is characteristic of the wet depressions. Important vascular plants include Eleocharis quinqueflora (= Eleocharis pauciflora, fewflower spikerush) in the moss lawn and Carex canescens (silvery sedge) on hummocks. The organic mat is bordered by an open water moat on the basin's outer edge. Within the moat the common vascular species include Menyanthes trifoliata (bog bean), Nuphar spp. (water- or pond-lily), Carex vesicaria (inflated sedge), and Utricularia minor (lesser bladderwort).

The forest of the surrounding upland slopes is dominated by Pinus contorta (lodgepole pine) with scattered Picea (hybrid swarm of Engelmann and white spruce) and Pinus albicaulis (whitebark pine); dominance in the undergrowth is shared by Spiraea betulifolia (shiny-leaf spiraea) and Juniperus communis (common juniper).

\section{Key Environmental Factors}

The organic mat is able to respond to seasonal water level changes by floating, thereby maintaining a relatively constant hydrologic regime; also modulating water level changes is the mass of peat which holds a large quantity of water.

\section{Rarity}

No sensitive species have yet been described from this site.

\section{Other Values}

Though small this site is an excellent example of organic mat development in a formerly open water basin, profiling common geomorphic and ecological succession processes.

\section{Land Use}

Adjacent lands and the fen proper are part of Management Area 16, which is designated as part of the suitable timber base. Livestock grazing occurs adjacent to the fen.

\section{Exotics}

No weeds have been documented from this site. 


\section{Uplands}

The hydrologic impacts of timber harvesting on the wetlands are unknown; usually the result is to increase groundwater and runoff and thus the fen's hydrologic regime could be impacted.

\section{Information Needs}

The initial survey of this site has documented communities and their distribution or composition at a fairly superficial level; it is most probable that a complex, microscale community patterning exits at this site. A weed and rare plant survey should also be conducted at and nearby the site. Land use practices on the uplands, as they affect the embedded wetlands, need documentation.

\section{Management Needs}

Fencing around the basin is needed to protect the site from livestock trampling. A more complete hydrologic profile would help to resolve issues of appropriate buffers and management practices were logging to occur in this drainage.

\section{Source}

Chadde, S. W., J. S. Shelly, R. J. Bursik, R. K. Moseley, A. G. Evenden, M. Mantas, F. Rabe, and B. Heidel. 1998. Peatlands on National Forests of the Northern Rocky Mountains: ecology and conservation. General Technical Report RMRS-GTR-11, U.S. Department of Agriculture, Forest Service, Rocky Mountain Research Station, Ogden, Utah.

\section{Element Occurrence Information}

\begin{tabular}{lcc}
\hline & \multicolumn{2}{c}{ Rarity Ranks } \\
Plant Association / Dominance Type & State & Global \\
\hline Sphagnum spp. Alliance & $*$ & $*$ \\
\hline$*$ Rank not assigned & &
\end{tabular}




\section{Nicholia Creek Mire}

\section{Directions}

A portion of this site is located on private land and consequently landowner permission is required to access the area. This complex of wetlands is located in southwest Beaverhead County approximately 24 air miles southwest of Lima, MT. From Dell take Big Sheep Creek Rd. (USFS Road \#302) westward approximately 14.5 miles to the intersection of USFS Roads 325 and 326; take Road 3269.8 miles to the south-southwest. The mire is about 3 miles upstream from the confluence of Tendoy Creek with Nicholia Creek. The mire occurs on both sides of Nicholia Creek in this vicinity.

\section{Description}

The mire occurs at 8,150 feet elevation, occupying both sides of Nicholia Creek and comprising approximately 200 acres. Parent materials in the area are dolomites and limestones of Mississippian and Pennsylvanian ages. Water perculating through these calcareous beds becomes somewhat alkaline ( $\mathrm{pH} 7.7$ to 8.0) before discharging from four springs supplying the wetland. Soils varied from fibrous peat to silts with a high humic content. This mire is a mosaic of at least five wetland communities. Carex aquatilis Deschampsia caespitosa (water sedge - tufted hairgrass) is a wet meadow type occurring on silty organic soils that are moist throughout most of the growing season but dry in the late summer. The nominal species are dominant as well, with auxiliary herbs Calamagrostis neglecta (slimstem reedgrass), Polemonium occidentale (western polemonium), and Symphyotrichum spathulatum (=Aster occidentalis, western aster). The Carex aquatilis - Carex aquatilis community is the dominant fen type on peaty soils; it is characterized by a nearly continuous $C$. aquatilis with Carex simulata (short-beaked sedge) and Carex utriculata (beaked sedge) being present but uncommon. Moist, fine-textured mineral soils with a high organic content are occupied by the Dasiphora fruticosa ssp. floribunda /Juncus balticus (shrubby cinquefoil / Baltic rush) community. Salix brachycarpa (short-fruited willow), Symphyotrichum spathulatum, and Taraxacum officinale (common dandelion) are the other species occurring commonly. On silty soils where the water table fluctuates markedly during the growing season, Salix boothii / Carex utriculata (Booth willow / beaked sedge) dominates, usually distributed immediately along the creek. On the floating mat of peat on the mire's west side Salix brachycarpa / Carex simulata (short-fruit willow / shortbeaked sedge) is dominant and characterized by a rather prostrate form and patchy representation of $S$. brachycarpa. Carex simulata occurs in high densities, but there are sparse areas with common Triglochin palustre (marsh arrow-grass), Epilobium palustre (swam willow-herb) and Eleocharis palustris (common spike-rush). Betula glandulosa (bog birch), Salix boothii, and Dasiphora fruticosa ssp. floribunda are scattered in this community.

\section{Key Environmental Factors}

An upwelling of relatively high $\mathrm{pH}$ waters from four springs provides a constant, calcium enriched water supply and creates areas with a stable high water table which experiences nearly constant anaerobic conditions conducive to the development of peat and fen vegetation. Areas with fluctuating water levels support meadow or shrub-dominated vegetation. Beaver (Castor canadensis) play an important role in the formation and maintenance of these wetlands.

\section{Rarity}

Two species formerly considered sensitive, Gentiana aquatica (wet meadow gentian) and Astragalus argophyllus var. argophyllus (silver-leaved milkvetch), occur within the complex. No other plant species or plant associations deemed sensitive or rare have been described from the site. 


\section{Other Values}

The wetlands authority examining this site rated it as one of the largest, most diverse and least disturbed wetland complexes in Beaverhead County. The large calcareous spring-fed fen with an extensive floating mat is noteworthy because of its high elevation occurrence.

\section{Land Use}

Though the mire and surrounding lands are closed to motorized travel, the trail adjacent to the fen is still used illegally by motorcyclists. This site has historically been and continues to be livestock grazed; meadows around the pond at the head of the complex have suffered extensive livestock induced damage (hummocking and compacting predominantly). The Continental Divide Trail passes along the north and east sides of the site and a major hiking trail to the Italian Peaks passes along the west side. Outfitter and hunter use occurs during hunting season. Due to its remoteness it receives relatively light use.

\section{Exotics}

The only noxious weed noted, Cirsium arvense (Canada thistle), is present in minor amounts. In the cattle-impacted portions of meadows the exotics Poa pratensis (Kentucky bluegrass) and Taraxacum officinale (common dandelion) are extensive.

\section{Uplands}

The uplands for this site have not yet been described, nor have any land uses, besides livestock grazing and recreation hiking, been documented.

\section{Information Needs}

The security and source of the water input to this system should be ascertained so that hydrologic interruption does not occur. The past grazing regime needs to be fully understood.

\section{Management Needs}

A livestock management plan is needed which addresses the susceptibility (to grazing and other disturbances) of wetlands early in the growing season and the general proclivity of cattle to habitually congregate in the riparian/wetland zone.

\section{Sources}

Lesica, P. 1990. Vegetation and sensitive vascular plants of Morrison Lake, Harkness Lakes and Nicholia Creek wetlands, Beaverhead County, Montana. Termination report to Beaverhead National Forest, Dillon, Montana.

\section{Element Occurrence Information}

\begin{tabular}{lcc}
\hline & \multicolumn{2}{c}{ Rarity Ranks } \\
Plant Association / Dominance Type & State & Global \\
\hline Carex aquatilis Herbaceous Vegetation & $\mathrm{S} 4$ & $\mathrm{G} 5$ \\
Carex aquatilis - Deschampsia caespitosa Herbaceous Vegetation & $\mathrm{S} 4$ & $\mathrm{G} 5$ \\
Dasiphora fruticosa ssp. floribunda / Juncus balticus Shrubland & $\mathrm{S} ?$ & $*$ \\
Salix brachycarpa / Carex simulata Shrubland & $*$ & $*$ \\
Salix boothii / Carex utriculata Shrubland & $\mathrm{S} 4$ & $\mathrm{G} 4$ \\
\hline * Rank & &
\end{tabular}

* Rank not assigned 


\section{North Fork Burns Creek Draws}

\section{Directions}

From Glendive, MT take State Highway 16 north to State Highway 254 towards Richey. Eleven miles north of Bloomfield follow the road going east toward a bible camp. Proceed six miles to a T-intersection and then proceed south for one mile and then east for 3.2 mile to a Y-intersection. From this point various portions of the site, especially the higher quality draws to the north, can be accessed.

\section{Description}

This site is found within the semi-arid mixed-grass prairie of eastern Montana on soils predominantly derived from sandstone and sedimentary alluvium. The total annual precipitation averages about 14 inches. Slopes of the site characteristically range from 5 to $45 \%$ and are dissected by numerous draws that concentrate the limited precipitation. Many of the draws face in a northeast direction, creating substantially more mesic conditions with extensive forest vegetation compared to the surrounding uplands. These wooded draws are dominated by Fraxinus pennsylvanica (green ash), Acer negundo (boxelder), and to a much lesser degree Ulmus americana (American elm). The subcanopy is dominated by Prunus virginiana (chokecherry) and other tall shrub species. The forests issuing from draws narrow and follow the subsidiary drainages into the main drainage. The herbaceous component exhibits a number of characteristic species including Oryzopsis micrantha (littleseed ricegrass), Carex sprengelii (Sprengel's sedge), Sanicula marilandica (black snakeroot), Disporum trachycarpum (wartberry fairybells) and Viola canadensis (Canada violet) found nowhere in the upland sites or grasslands. The hardwood communities interdigitate with grassland dominated by Hesperostipa comata (needle-and-thread), Pascopyrum smithii (western wheatgrass), Koeleria macrantha (prairie junegrass). Where erosion is active Juniperus horizontalis (creeping juniper) and Schizachyrium scoparium (little bluestem) dominate depauperate communities.

\section{Key Environmental Factors}

Woody draws are dependent on the mesic conditions generated by the steep north- and northeast-facing slopes with a concave configuration that further concentrates slopewash and infiltrated waters.

\section{Rarity}

The woody draws of eastern Montana are usually of small size and heavily impacted by grazing practices and timber cutting. The woody draw communities of North Fork Burns Creek are highly ranked examples because of their size, continuity, relative lack of disturbance, and the presence of an uncommon plant community, Fraxinus pennsylvanica - Ulmus americana / Prunus virginiana. The main flowage of Burns Creek also represents a quality native prairie-stream habitat with 12 species of native fishes.

\section{Other Values}

The vegetation of woody draws is crucial to reducing erosion and modulating steamflow. Woody draws are exceedingly important multi-storied wildlife habitat within a vast matrix of limited structure farmland and mixed-grass prairie; these areas attract large ungulates for cover and thermal protection as well as a great diversity of bird species.

\section{Land Use}

Livestock impacts like vegetation composition alteration, trampling and the introduction of exotics are affecting the draws, especially sites less steep and close to water. Degradation of the vegetation will affect fishery and water quality through siltation and eutrophication. 


\section{Exotics}

Poa pratensis (Kentucky bluegrass) and Taraxacum officinalis (common dandelion), though not noxious weeds, can proliferate to the point of reducing species diversity within native vegetation.

\section{Uplands}

Mostly dryland agriculture is practiced on the Butler Table, a benchland above and south of the draws, with some poorer sites remaining in native mixed-grass prairie dominated by Hesperostipa comata and Pascopyrum smithii. Upland sites to the north of Burns Creek are mostly held by energy concerns with interests in coal extraction.

\section{Information Needs}

The reasons for the poor reproduction of Ulmus americana (American elm) should be identified; it should also be established whether Dutch elm disease has infested these stands. A more intensive survey for exotic species should be undertaken. A more extensive fishery and aquatic invertebrate inventory needs to be conducted in addition to a determination of local wildlife use and population status.

\section{Management Needs}

Livestock and wild ungulate grazing needs to be monitored. Stocking numbers probably should be reduced. Coal development could have serious consequences to these wetlands.

\section{Source}

Field inventory records are on file with the Montana Natural Heritage Program.

Element Occurrence Information

\begin{tabular}{lcc}
\hline & \multicolumn{2}{c}{ Rarity Ranks } \\
Plant Association / Dominance Type & State & Global \\
\hline Fraxinus pennsylvanica / Prunus virginiana Forested Vegetation & S2S3 & G3? \\
Pascopyrum smithii - Hesperostipa comata Herbaceous Vegetation & S? & G4 \\
Pseudoroegneria spicata - Pascopyrum smithii (Elymus lanceolatus) Herbaceous & & \\
Vegetation & S4 & G4 \\
\hline
\end{tabular}




\section{Pine Butte Fen}

\section{Directions}

This site is wholly contained within the Pine Butte Preserve administered by the Montana Field Office of The Nature Conservancy. The preserve is located in west-central Teton County, MT, $45 \mathrm{~km}$ (28 mi.) west of Choteau; it extends from the east slope of Ear Mountain and Indian Head Rock east to the confluence of McDonald Creek and the Teton River. From Choteau take Route 89 north 4.7 miles to a county road that parallels the north bank of the Teton River. Drive west on this road about 13 miles then turn south on a ranch road, crossing the Teton River within $0.4 \mathrm{mi}$. Continue on this road 1.6 miles beyond the Teton River following signs to Pine Butte Preserve headquarters. Check with preserve managers for permission (spring access restricted due to Grizzly Bear use) and information regarding best access to the Pine Butte Fen.

\section{Description}

The preserve extends from the east slope of Ear Mountain and Indian Head Rock east to the confluence of McDonald Creek and the Teton River, but the 450 ha (1,110 acres) fen lies immediately to the west of Pine Butte and has a gentle southeast-trending slope. The Pine Butte Fen has shale bedrock of Cretaceous origin whereas the mountainous western half is formed of Paleozoic limestones and shales with drainage patterns from west to east via the Teton River, Willow Creek and McDonald Creeks. The fen is on glacial drift derived from limestones and calcareous shales. This permeable drift, layered on impermeable bedrock, is saturated by water flowing southward from the Teton River. This continuously flowing, cold and nutrient-rich water intercepts the ground surface at the fen. Mean annual precipitation is $430 \mathrm{~mm}$; mean annual temperature is $6.0^{\circ} \mathrm{C}\left(42.8^{\circ} \mathrm{F}\right)$; and an average of 90 days are frost-free.

Surrounding upland vegetation is mid-grass and foothills bunchgrass prairie dominated by graminoids such as Pseudoroegneria spicata (Bluebunch Wheatgrass), Festuca campestris (Rough Fescue), Festuca idahoensis (Idaho Fescue), Bouteloua gracilis (Blue Grama), Achnatherum spp. and Hesperostipa comata (Needle-and-thread). Local hills and buttes support very open woodlands dominated by Pinus flexilis (Limber Pine) and Pseudotsuga menziesii (Douglas-fir) with bunchgrass undergrowth. Riparian vegetation along the Teton River is dominated by Populus balsamifera ssp. trichocarpa (Black Cottonwood, on loamy soils and having relatively little disturbance) and Populus angustifolia (Narrowleaf Cottonwood, on disturbed, gravelly substrates) with both wet (continuously saturated soils) and relatively dryer Salix spp. (willow species) communities. Other vegetation types identified in the vicinity of the fen include montane riparian marshes, graminoid-dominated wet meadows, ponds with floating and submersed species, and prairie pond drawdown zones.

Of the three fen types (open fen, carr, and dwarf-carr), the open fen is by far the most extensive, comprising approximately 300 ha. and occupying the central portion of the Duhr Fen. The open fen has poorly drained fibrous organic soils (peat) of the Dougcliff Series; many areas are so unconsolidated and saturated that a "quaking" is felt with every step. A well-developed hummock-hollow micotopography typifies the surface of the peat. The hummocks coalesce to form small ridges (strings) about $0.5 \mathrm{~m}$ high and 0.5-1.0 m wide. The hollows between strings are called flarks and are about 0.5-2.0 $\mathrm{m}$ wide with standing water present during all or most of the growing season. These two distinct habitats also reflect a patterning of the vegetation. The hummock vegetation is a mosaic of graminoids and bryophytes including Carex simulata (Analogue Sedge), Carex aquatilis (Water Sedge), Juncus balticus (Baltic Rush), and Muhlenbergia glomerata (Spiked Muhly); the shrubs Betula glandulosa (Bog Birch) and Dasiphora fruticosa ssp. floribunda (= Potentilla fruticosa, Shrubby Cinquefoil) are scattered with less than $25 \%$ cover. Common forbs include Triglochin maritimum (Seaside Arrowgrass), Galium boreale (Northern Bedstraw), Symphyotrichum boreale (=Aster juncifomis, Northern Bog Aster), Viola nephrophylla (Northern 
Bog Violet), and Dodecatheon pulcherrimum. Forming an almost continuous ground cover are the mosses Campylium stellatum and Limprichtia revolvens (= Drepanocladus revolvens). Flarks are dominated by aquatic dicots, including Utricularia vulgaris (Common Bladderwort), Utricularia minor (Lesser Bladderwort), Menyanthes trifoliata (Buckbean) and the mosses Scorpidium scorpioides and Limprichtia revolvens; commonly occurring graminoids include Carex simulata, Carex livida (Livid Sedge) and Eleocharis quinqueflora (=E. pauciflora, Fewflower Spikerush). A Schoenoplectus acutus (= Scirpus acutus, Hardstem Bulrush) dominated community occurs in 1-5 ha patches throughout the open fen, partially replacing the above described communities on both strings and flarks. Both Betula glandulosa and Dasiphora fruticosa have greater cover and height within these Schoenoplectus patches.

The carr community exhibits a hummock-hollow mirotopography, but distinct flarks and strings are lacking. Standing water is present through virtually all of the growing season. The poorly drained, organic soils belong mostly to the Winginaw Series. Mid-sized to tall shrubs, ranging in height from 1 to $3 \mathrm{~m}$, are dominant and include Betula glandulosa, Salix monticola (Park Willow), Salix planifolia (Diamondleaf Willow), Salix serissima (Autumn Willow) and Cornus sericea (= Cornus stolonifera, Red-Osier Dogwood). Water-filled depressions surrounding the shrubs are dominated by the large sedges, Carex utriculata (Beaked Sedge) and Carex aquatilis (Water Sedge), and Equisetum laevigatum (Smooth Horsetail). Mosses are confined to the bases of shrubs and forbs are sparsely represented.

The dwarf-carr is dominated (cover greater than $30 \%$ ) by shrubs ranging in height from $0.5 \mathrm{~m}$ to $2.0 \mathrm{~m}$. In structure and composition it is intermediary between the carr and open fen type. This type is most common along the fen edges, between open fen and carr, surrounding open water ponds and in patches throughout the open fen. Like the carr, distinct strings and flarks are not distinguishable but hummockhollow microrelief is present. Dominant shrubs, which occur only on hummocks, include Dasiphora fruticosa, Betlua glandulosa, Cornus sericea, and, most significantly, Salix candida (Hoary Willow), an uncommon species strongly associated with well-developed peatlands. Most forbs, including Triglochin maritimum and Galium boreale, are limited to hummocks. Equisetum laevigatum and Equisetum arvense (Field Horsetail) occur on both hummocks and hollows. The mosses Campylium stellatum and Rhyncostegiella compacta are found on hummocks beneath litter.

Stands of a wet and poorly described Populus tremuloides (Trembling Aspen) type with surface water present have been noted throughout the fen; Populus tremuloides forms the overstory and a secondary, sometimes dense canopy is comprised of Betula occidentalis (River Birch), Salix bebbiana (Bebb's Willow), Salix lutea (Yellow Willow) and Cornus sericea. The herbaceous layer is species rich; any of the following can be dominant, Equisetum arvense, Equisetum laevigatum, Agrostis stolonifera (Redtop), Glyceria striata (Fowl Mannagrass), Calamagrostis stricta ssp. inexpansa (Northern Reedgrass), Heracleum maximum (= Heracleum lanatum, Cow Parsnip), Sanicula marilandica (Maryland Sanicle), Angelica arguta (Lyall's Angelica), and Geum macrophyllum (Largeleaf Avens).

\section{Key Environmental Factors}

The primary environmental factor influencing mire vegetation is the mineral concentration of the water; a gradient of mineral-poor (ombrotrophic) to mineral-enriched (minerotrophic) water determines the continuum of bog to rich fen, respectively. Pine Butte Fen is mostly representative of rich fens, having 91 vascular plant species (some of which are calciphiles) and many of the moss species (e.g., Scorpidium scorpioides, Drepanocladus revolvens, Campylium stellatum) are considered rich fen indicators. The floristic uniqueness of Pine Butte Fen is attributable to its climate, which is arid and continental, unlike all other significant mire systems of this type which occur in temperate, warm temperate, boreal or arctic zones. Two observations point to the uniqueness of the Pine Butte Fen: 1) Sphagnum mosses, Drosera spp., ericaceous shrubs, and other "acid-loving" species are notably absent from Pine Butte, 2) a large number of Pine Butte fen species originate from the adjacent grassland communities adapted to the re- 
gional aridity. Though beaver activity is more associated with marsh and pond formation, it could have an influence on the fen beyond the obvious browsing of the Salix spp. and Populus spp. components and the localized flooding in the carr which impedes the growth of woody plants.

\section{Rarity}

The fen contained the following Montana species of concern plants (as of the year 2002); Carex livida (Pale Sedge; wet, peaty soils of calcareous regions), Carex crawei (Craw's Sedge; wet places associated with calcareous substrates), Salix serissima (Autumn Willow; in carr, scattered in open fen), Primula incana (Mealy Primrose; pond margin). Only one species of potential concern was recorded, Eriophorum viridicarinatum (Thinleaf Cottonsedge).

\section{Other Values}

Pine Butte Fen is without question the premier calcareous mire of its kind in Montana and perhaps all of the Pacific Northwest in terms of size, diversity of communities and species, and condition. It is one of a very limited number of sites (perhaps fewer than four) that Ursus arctos horribilis (Grizzly Bear), listed federally as threatened, ranges onto the plains in the spring, foraging for herbs and animal carcasses. The fen is also part of the territory of a pack of Canis lupus (Gray Wolf), also federally listed (Endangered).

\section{Land Use}

Livestock use occurs over the whole of the Pine Butte Preserve, but has been severely curtailed in the wetlands vicinity due to trampling effects. Mowing of meadows and drier portions of the fen on an annual basis has occurred historically, encouraging the increase of Eurasian meadow grasses as well as Juncus balticus and Eleocharis palustris.

\section{Exotics}

The author of the report lists only Agrostis stolonifera and Taraxacum officinale as introduced species, neither of which had developed significant populations. Euphorbia esula (Leafy Spurge) is present in the uplands. The drier portions of the carr would also constitute potential habitat

\section{Uplands}

In the past cattle grazing and mowing of lush meadows was routine, but mowing has been curtailed. The uplands constitute some of the highest quality rangeland to be found on the Rocky Mountain Front due to management by The Nature Conservancy. Their approach to weed control is both intensive and experimental.

\section{Information Needs}

The site-specific plant composition data collected on Pine Butte Fens is among the best existing for privately held wetlands. It should be incorporated into the Heritage database for long-term monitoring purposes and some sites should be resampled with GPS to increase the efficiency of the long-term monitoring.

\section{Management Needs}

Following an inventory for weeds, those of noxious status should be eradicated and a plan should be implemented to reduce or curtail the spread of exotic pasture grasses and other exotics (e.g., Taraxacum officinale). 


\section{Sources}

Lesica, P. 1982. Vegetation of the wetland and riparian areas of Pine Butte Preserve, Teton County, Montana. Report to The Nature Conservancy, Big Sky Field Office, Helena, MT.

Lesica, P. 1986. Vegetation and flora of Pine Butte fen, Teton County, Montana. Great Basin Naturalist 46:22-32.

McAllister, D. C. 1990. Plant community development in a minerotrophic peatland, Teton County, Montana. Ph.D. Dissertation, University of Montana.

\section{Element Occurrence Information}

\begin{tabular}{lcc}
\hline & \multicolumn{2}{c}{ Rarity Ranks } \\
Plant Association / Dominance Type & State & Global \\
\hline Populus tremuloides / Equisetum arvense Forest & $\mathrm{S} ?$ & $\mathrm{G} 4$ \\
Betula glandulosa / Carex interior Dominance Type & $*$ & $*$ \\
Betula glandulosa / Carex simulata Provisional Shrubland & $\mathrm{S} ?$ & $\mathrm{G} ?$ \\
Betula glandulosa / Carex aquatilis Dominance Type & $*$ & $*$ \\
Betula glandulosa / Schoenoplectus acutus Dominance Type & $*$ & $*$ \\
Carex simulata Herbaceous Vegetation & $\mathrm{S} 3$ & $\mathrm{G} 4$ \\
Eleocharis quinqueflora Herbaceous Vegetation & $\mathrm{S} 3$ & $\mathrm{G} 4$ \\
Carex limosa Herbaceous Vegetation & $\mathrm{S} 2$ & $\mathrm{G} 2$ \\
Schoenoplectus acutus Herbaceous Vegetation & $\mathrm{S} 5$ & $\mathrm{G} 5$ \\
\hline
\end{tabular}

* Rank not assigned 


\section{Potosi Hot Spring}

\section{Directions}

At least a portion of this site is located on private land and consequently landowner permission is required to access that area. Access this site by driving from Pony, Montana (at the terminus of State Route 283) southward on U.S. Forest Service Road \#160 approximately 7.8 miles; the site is about 0.95 miles beyond the confluence of South Willow Creek and Potosi Creek. The spring is located on private land approximately 50 feet upslope from the road (\#160).

\section{Description}

Potosi Hot Springs is located on the east flank of the Tobacco Root Mountains at 6,160 feet elevation. The springs issue from a steep slope 50 feet above the valley bottom of South Willow Creek and flow downslope as several rivulets. Wetland vegetation is developed on the slope and also occurs on the slope bottom. The wetland vegetation included the following types, Eleocharis rostellata (beaked spike-sedge, characterizing the wettest, warmest environments), Eleocharis pauciflora (few-flowered spike-sedge), and Eleocharis palustris (common spike-sedge); all communities are virtually monospecifically dominated by the nominal species.

\section{Key Environmental Factors}

Hot water from a subterranean source continuously rises to the surface and spills down the slope as the predominant source of groundwater to this site.

\section{Rarity}

Eleocharis rostellata, in addition to being considered a rare plant, dominates and defines a rare community type. Epipactis gigantea (giant helleborine) is the other rare wetland plant present.

\section{Other Values}

At the time of inventory the wetland vegetation appeared to be in near-pristine condition. This hot spring habitat supports a population of lightning bugs (Family Lampyridae) and may support other rare insects or invertebrates because of the uniqueness of the habitat.

\section{Land Use}

The springs are undeveloped with the exception of a minor diversion of hot water to the owner's house to fill a small pool. The near-pristine condition reflects the lack of use of the springs as well as the adjacent uplands.

\section{Exotics}

This factor was not explicitly noted in the report.

\section{Uplands}

This factor was not explicitly noted in the report, nor could it be inferred.

\section{Information Needs}

Protecting the biological value of the site is clearly dependent upon understanding its hydrology, which has not yet been elucidated. Hansen et al. 1995 consider sites dominated by Eleocharis rostellata to be ecologically equivalent to those dominated by Eleocharis quinqueflora (formerly E. pauciflora) and ac- 
cording has designated the community name to be E. quinqueflora. The MTNHP believes there is sufficient habitat distinction reflected by the dominance of these respective species to warrant separate community names but more site-specific data is needed to elucidate their respective ecologies. Apparently exotic species, noxious or merely aggressive aliens, have not been inventoried to date.

\section{Management Needs}

The water diversion to the house should perhaps be maintained at a minimum or at least account for the amount of water currently diverted, so that the wetlands can be maintained in their present condition and extent.

\section{Source}

Lesica, P. 1990. Vegetation and sensitive plant species of wetlands associated with geothermal areas in the Greater Yellowstone Ecosystem in Montana. Report to The Nature Conservancy, Helena, MT.

\section{Element Occurrence Information}

\begin{tabular}{lcc}
\hline & \multicolumn{2}{c}{ Rarity Ranks } \\
Plant Association / Dominance Type & State & Global \\
\hline Eleocharis palustris Herbaceous Vegetation & $\mathrm{S} 5$ & $\mathrm{G} 5$ \\
Eleocharis quinqueflora Herbaceous Vegetation & $\mathrm{S} 3$ & $\mathrm{G} 4$ \\
Eleocharis rostellata Dominance Type & $\mathrm{S} 1$ & $*$ \\
\hline
\end{tabular}

* Rank not assigned 


\section{Tepee Lake Candidate Botanical Area}

\section{Directions}

Tepee Lake is situated about 15 air miles south-southwest of Libby, MT in the Libby Creek/Swamp Creek watershed at the headwaters of an unnamed tributary to Cowell Creek. The site is most easily accessed from US Route 2 via Forest Road 6740 which branches to the west from Route 2 about 19.4 miles south of Libby. Follow Forest Road 6740 for a sinuous 4.3 miles in a northerly direction. Good access to the wetland occurs where Forest Road 866 branches to the north.

\section{Description}

Tepee Lake is a small (10 acre approximately) pond with a floating organic mat, which is surrounded by an anchored organic mat of some 15 acres. Dominant species of the organic mat include Carex lasiocarpa (slender sedge), Carex utriculata (beaked sedge), Carex limosa (mud sedge), and Dulichium arundinaceum (dulichium). A rich moss layer including Sphagnum subsecundum, Tomentypnum nitens, Aulacomnium palustre, Calliergon giganteum, and Pohlia longicolla, has developed on the mat surface.

\section{Key Environmental Factors}

This pond, surrounding fen and shrublands are dependent on groundwater recharge via snowmelt. The hydrologic regime probably responds primarily to climatic fluctuations and possibly beaver activity downstream from the ponds overflow point.

\section{Rarity}

Two Montana rare plants occur on the floating mat portion of the peatlands, Drosera anglica (English sundew) and Scheuchzeria palustris (pod grass). A state rare wetland plant community, Carex limosa Herbaceous Vegetation, may also be present since it is listed a dominant graminoid over portions of the area.

\section{Other Values}

The organic floating mat and the anchored portion constitute a significant development of a fen vegetation type and associated peatland that is not well represented in the state.

\section{Land Use}

Lands surrounding the lake are managed for timber and only a narrow forested buffer exists between the peatland and cutover lands.

\section{Exotics}

No exotics were detailed in the initial inventory.

\section{Uplands}

Uplands surrounding the lake are potentially forested but have been cutover resulting in shrub-dominated canopies at the current stage of succession.

\section{Information Needs}

A much more detailed inventory in needed to document threats from exotic species, the type and condition of native plant communities and additional populations of rare or sensitive plants and animals. For 
example, this site has habitat appropriate for Synaptomys borealis (northern bog lemming), but a survey for this species has not yet been conducted.

\section{Management Needs}

This site appears, based on limited field inventory, deserving of being designated a Botanical Special Interest Area.

\section{Source}

Chadde, S. W., J. S. Shelly, R. J. Bursik, R. K. Moseley, A. G. Evenden, M. Mantas, F. Rabe, and B. Heidel. 1998. Peatlands on National Forests of the Northern Rocky Mountains: ecology and conservation. General Technical Report RMRS-GTR-11, U.S. Department of Agriculture, Forest Service, Rocky Mountain Research Station, Ogden, Utah.

\section{Element Occurrence Information}

\begin{tabular}{lcc}
\hline & \multicolumn{2}{c}{ Rarity Ranks } \\
Plant Association / Dominance Type & State & Global \\
\hline Carex lasiocarpa Herbaceous Vegetation & $\mathrm{S} 4$ & $\mathrm{G} 4 ?$ \\
Carex limosa Herbaceous Vegetation & $\mathrm{S} 2$ & $\mathrm{G} 2$ \\
Carex utriculata Herbaceous Vegetation & $\mathrm{S} 5$ & $\mathrm{G} 5$ \\
Dulichium arundinaceum Herbaceous Vegetation & $\mathrm{S} 2$ & $\mathrm{G} 3$ \\
\hline
\end{tabular}




\section{Trudeau Warm Springs}

\section{Directions}

From Alder, Montana at the south end of the Ruby Valley travel 1.3 miles southeast on State Route 287 to the junction with the Ruby Valley Road and then take this road (which is initially paved but transitions to a well-maintained dirt road) to the southern end of Ruby River Reservoir. Take the first dirt road branching to the west from the Ruby Valley Road (at the head of the reservoir), and stay on this dirt road as it swings back northward skirting the west shore of the reservoir. At mid-reservoir the road swings to the west up Garden Creek. Approximately $0.5 \mathrm{mi}$ up Garden Creek take the fork to the north, traveling about 0.7 miles to the vicinity of the warm springs, which are roughly 100 meters above the road.

\section{Description}

This wetland is fed by a warm spring that issues forth on a bench above the Ruby River Reservoir. The spring feeds a small pond (Trudeau Lake) that overflows down the travertine-covered slope to the floodplain below. Seepage waters also occur along areas of the bench, which have extensive travertine deposits. Extensive areas of wetland vegetation cover the travertine slopes and the floodplain. The following communities have been noted, but not extensively described: Dasiphora fruticosa ssp. floribunda / Deschampsia caespitosa (shrubby cinquefoil), Sarcobatus vermiculatus / Leymus cinereus (black greasewood / basin wild rye), Eleocharis rostellata (beaked spike-rush), Eleocharis quinqueflora (few-flowered spike-sedge), and Deschampsia caespitosa (tufted hairgrass). The Dasiphora fruticosa / Deschampsia caespitosa community that develops on travertine is saturated until mid-summer and this high moisture status is indicated by the considerable cover of Carex pellita (= Carex lanuginosa, wooly sedge), Juncus balticus (Baltic rush), and Triglochin maritima (seaside arrow-grass). The Sarcobatus vermiculatus / Leymus cinereus community includes Distichlis spicata (inland saltgrass) and Pascopyrum smithii (western wheatgrass) as the common ground layer species. Also present is an aquatic community dominated by Stuckenia pectinatus (= Potamogeton pectinatus, sago pondweed) and Zannichellia palustris (horned pondweed).

The surrounding uplands are dominated by Artemisia tridentata ssp. vaseyana (mountain big sagebrush), Artemisia nova (black sagebrush), and various bunchgrasses including Festuca idahoensis (Idaho fescue) and Pseudoroegneria spicata (bluebunch wheatgrass). Juniperus scopulorum (Rocky Mountain juniper) woodlands are also part of the vegetation matrix.

\section{Key Environmental Factors}

The continued upwelling of spring-fed mineral rich (especially calcium carbonate) warm waters provides the unique environment of this site.

\section{Rarity}

Two sensitive plant species, Packera debilis (= Senecio debilis, weak butterweed) and Eleocharis rostellata (beaked spike-rush), occur at this site. The nearly monospecific dominance of this Eleocharis species also defines a rare Montana community type. This hotsprings environment supports a globally endangered riffle beetle, Zaitzevia thermae (Warm Springs Zaitzevian Riffle Beetle) as well as a population of lightning bugs (Family Lampyridae) and may have other rare insects or invertebrates (due to the uniqueness of the site). 


\section{Other Values}

This site exhibited the greatest diversity of plant communities of all geothermal areas surveyed within the state. The wetland vegetation is generally in good condition.

\section{Land Use}

The area is grazed by livestock, but appears to be in good range condition. Locals have introduced tropical fish populations (mollies, guppies) to the spring, which may now serve as a source for commercial suppliers; the impact of these exotic species on native fauna has not been explored.

\section{Exotics}

Cirsium arvense (Canada thistle, a noxious weed), Poa pratensis (Kentucky bluegrass, non-native increaser species), and Sonchus arvensis ssp. uliginosus (= Sonchus uliginosus, sow thistle, native increaser) have invaded the site and surrounding terrain but none of the populations are significant. This low level of invasion does not necessarily signal that past grazing abuses have occurred.

\section{Uplands}

Upland land uses have not been documented other than the noting of ubiquitous livestock grazing.

\section{Information Needs}

The hydrologic source of the warm springs is unknown, but should be established to prevent the interruption of flow to the groundwater discharging to this system. The grazing regime should be documented so that it (or a similarly favorable system) can be implemented into the future, since it ostensibly has resulted in "good" condition wetlands. A weed survey, including a broad spectrum of non-native increasers, needs to be conducted.

\section{Management Needs}

A grazing plan needs to be formulated and implemented to provide for continued maintenance of the quality of this wetland. The impact of recreational use on this site (local swimming hole) should be ascertained as well.

\section{Source}

Lesica, P. 1990. Vegetation and sensitive plant species of wetlands associated with geothermal areas in the Greater Yellowstone Ecosystem in Montana. Report to The Nature Conservancy, Helena, MT.

\section{Element Occurrence Information}

\begin{tabular}{lcc}
\hline & & \\
Plant Association / Dominance Type & \multicolumn{2}{c}{ Rarity Ranks } \\
Dasiphora fruticosa ssp. floribunda / Deschampsia caespitosa & Shrubland & Global \\
\hline Deschampsia caespitosa Herbaceous Vegetation & $\mathrm{S} 4$ & $\mathrm{G} 4$ \\
Eleocharis quinqueflora Herbaceous Vegetation & $\mathrm{S} 4$ & $\mathrm{G} 4$ \\
Eleocharis rostellata Dominance Type & $\mathrm{S} 3$ & $\mathrm{G} 4$ \\
Sarcobatus vermiculatus / Leymus cinereus Shrubland & $\mathrm{S} 1$ & $*$ \\
\hline
\end{tabular}

* Rank not assigned 


\section{Whitefish Spruce Swamp Preserve}

\section{Directions}

Whitefish Spruce Swamp is located in the Flathead Valley about 1 air mile north of Whitefish, MT. Landowner permission is needed to access the property. Follow Highway 93 through Whitefish to Wisconsin Avenue, turning right onto this avenue and proceed over the overpass. One mile past the overpass turn right onto Reservoir Road. Proceed $1 / 8^{\text {th }}$ mile on Reservoir Road to driveway on right.

\section{Description}

The general setting of the Whitefish Spruce Swamp is the Rocky Mountain Trench, at the margin of the Flathead Valley. The site is located at the toe of a slope where groundwater from the adjacent uplands flows to the surface, keeping the site saturated for most of the year. Of the four plant communities found at this site two are hygric to hydric wet spruce forest. A spruce hybrid swarm occupies the canopy of both the hydric Picea engelmannii / Lysichiton americanum (Engelmann spruce / skunk cabbage) association and the drier Picea engelmannii / Clintonia uniflora (Engelmann spruce / queen's cup beadlily) association. Soils are saturated to the surface year-round in the Picea / Lysichiton community and surface water flows in small channels through this nearly flat ground, which exhibits considerable microtopographic relief. Picea hybrids dominate the overstory, which also has some large Populus balsamifera ssp. trichocarpa (black cottonwood) and Betula papyrifera (paper birch). The shrub and herbaceous layer are species rich with the shrub layer dominated by Alnus incana (mountain alder) and the herbaceous layer by Lysichiton americanum, which occupies the shallow swales that have standing water for part of the year. The Picea / Clintonia is also Picea-dominated with scattered Populus balsamifera ssp. trichocarpa and Populus tremuloides (trembling aspen). The diverse shrub layer is commonly dominated by Symphoricarpos albus (common snowberry) and Amelanchier alnifolia (serviceberry). Clintona uniflora and Linnaea borealis (twinflower) dominate the herbaceous/dwarf-shrub layer. The other two communities documented from this site are Salix bebbiana (Bebb's willow) and an Agrostis stolonifera (redtop) wet meadow. In addition to Salix bebbiana the dominant shrubs in the willow community are Cornus sericeus (= Cornus stolonifera, red osier dogwood) and Alnus incana. The undergrowth component is characterized by Carex aquatilis (water sedge), Phalaris arundinacea (reed canarygrass), Agrostis stolonifera, and Carex flava (yellow sedge). The non-native Agrostis stolonifera community, probably a result of past grazing and haying practices, occurs adjacent to the willow community and is dominated by graminoids, especially redtop and includes Carex flava, Carex nebrascensis (Nebraska sedge), Carex pellita (= Carex lanuginosa, wooly sedge), and Phleum pretense (timothy).

\section{Key Environmental Factors}

An uninterrupted supply of groundwater from an upslope source is critical to the formation and maintenance of this wetland.

\section{Rarity}

Picea engelmannii / Lysichiton americanum is a rare plant association which occurs here as an extensive and high condition example. A number of Montana sensitive plants occur here, including Cypripedium parviflorum v. calceolus (yellow lady's slipper), Dryopteris cristata (Buckler fern), Viola renifolia (kidney-leaved violet), Halenia deflexa (American spurred gentian), and Geocaulon lividum (northern bastard toadflax). 


\section{Other Values}

Owners report that a variety of wildlife use the site. Moose and white-tailed deer were observed at the time of site inventory.

\section{Land Use}

This site has been selectively logged in the distant past leaving old rotting stumps. The Salix bebbiana and Agrostis stolonifera communities occur on land that was once spruce forest, but which has been cleared in the past for pasture; light horse and cattle grazing occurs in these communities

\section{Exotics}

A number of exotic plant species occur on the site, but they currently do not, and in the absence of disturbance will not, pose a threat to the Picea forest. As a result of past logging and grazing practices one community, Agrostis stolonifera (redtop), is already characterized by exotic pasture grass dominance. Three aggressive exotics, Cirsium arvense (Canada thistle), Sonchus arvensis ssp. uliginosus (= Sonchus uliginosus, field sowthistle), and Phleum pratensis (timothy), occur in the Salix and Agrostis communities and could pose a threat. The most significant threat is posed by Phalaris arundinacea (reed canarygrass), a broadly adapted, aggressive, rhizomatous species that has invaded both forested and open wet environments, regardless of whether these populations are native or introduced stock (see Merigliano and Lesica 1998).

\section{Uplands}

Near this site, and most threateningly upslope, there is road-building and residential development occurring. Plant community composition could be altered through the disruption of groundwater flow to the site by roadcuts and homesites or with nutrient loading from septic systems. In addition, trespass instances could facilitate the spread of weeds and disrupt wildlife patterns.

\section{Information Needs}

More information on hydrology is a primary need, particularly in regard to road and residential development. Since much of the projected development has occurred and short-term effects have apparently been benign the long-term effects need to be explored.

\section{Management Needs}

A program to monitor weeds and hydrology is necessary to detect changes resulting from disturbance and development.

\section{Sources}

Lesica, P. 1987. Montana preserve design package : Whitefish Spruce Swamp. Report to The Nature Conservancy, Helena, MT.

Merigliano, M. F. and P. Lesica. 1998. The native status of reed canarygrass (Phalaris arundinacea L.) in the inland northwest, USA. Natural Areas Journal 18: 223-230. 


\section{Element Occurrence Information}

\begin{tabular}{lcc}
\hline & \multicolumn{2}{c}{ Rarity Ranks } \\
Plant Association / Dominance Type & State & Global \\
\hline Agrostis stolonifera Herbaceous Vegetation & $\mathrm{S} 5$ & $\mathrm{GM}$ \\
Picea engelmannii / Clintonia uniflora Forest & $\mathrm{S} 4$ & $\mathrm{G} 4$ \\
Picea engelmannii / Lysichiton americanus Forest & $\mathrm{S} 2$ & $\mathrm{G} 2$ \\
Salix bebbiana Shrubland & $\mathrm{S} 3 ?$ & $\mathrm{G} 3 ?$ \\
\hline
\end{tabular}


APPENDIX A. GLOBAL/STATE RANK DEFINITIONS 


\section{Heritage Program Ranks}

The international network of Natural Heritage Programs employs a standardized ranking system to denote global (range-wide) and state status (NatureServe 2002). Species are assigned numeric ranks ranging from 1 (critically imperiled) to 5 (demonstrably secure), reflecting the relative degree to which they are "at-risk". Rank definitions are given below. Anumber of factors are considered in assigning ranks - the number, size and distribution of known "occurrences" or populations, population trends (if known), habitat sensitivity, and threat. Factors in a species' life history that make it especially vulnerable are also considered (e.g., dependence on a specific pollinator).

\section{Rank Definitions}

G1 S1 Critically imperiled because of extreme rarity and/or other factors making it highly vulnerable to extinction.

G2 S2 Imperiled because of rarity and/or other factors making it vulnerable to extinction.

G3 S3 Vulnerable because of rarity or restricted range and/or other factors, even though it may be abundant at some of its locations.

G4 S4 Apparently secure, though it may be quite rare in parts of its range, especially at the periphery.

G5 S5 Demonstrably secure, though it may be quite rare in parts of its range, especially at the periphery.

GU SU Possibly imperiled, but status uncertain; more information needed.

GA SA Native in nearby states, but in Montana believed to be accidentally introduced, deliberately planted, or escaped from plantings.

GH SH Historical, known only from records over 50 year ago; may be rediscovered.

GX SX Believed to be extinct; historical records only.

\section{Combination Ranks}

$\mathrm{G} \# \mathrm{G} \#$ or $\mathrm{S} \# \mathrm{~S} \#$ Indicates a range of uncertainty about the rarity of the species.

\section{Subranks}

T\#

Rank of a subspecies or variety; appended to the species' global rank of the full species, e.g. G4T3.

\section{Qualifiers}

Q

Taxonomic questions or problems exist, more information needed; appended to the global rank, e.g. G3Q.

Denotes uncertainty or for numeric ranks, inexactness. 